\title{
SHEAR STRENGTH CHARACTERISTICS OF NORMALLY CONSOLIDATED SILT - CLAY MATRICES
}

\author{
Dr. Krishna Nandan Prasad \\ Associate Professor, Katihar Engineering College, \\ Katihar, Bihar, India \\ Dr. Achintya* \\ Principal, Darbhanga College of Engineering, Bihar, India \\ *Corresponding Author
}

\begin{abstract}
Soil in the region of eastern Bihar has high percentage of kaolinite which leads to foundation problems. The rapid growth of industrialisation, modernisation and exodus of people from rural areas to urban ones has generated the necessity of large scale construction of various structures in this zone of eastern Bihar. At present, no systematic information is available for the design of foundation in this area. Hence, it is imperative to carry out systematic study to find out the most suitable silt-clay matrices to improve the bearing capacity of soil to prevent the foundation problems in this region on account of high percentage of kaolinite.
\end{abstract}

Keywords: Normally Consolidated Silt - Clay Matrix, Liquid Limit, Plastic Limit, Mohr's Circle, Cohesion, Angle of Internal Friction, Ultimate and Safe Bearing Capacity

Cite this Article: Krishna Nandan Prasad and Achintya, Shear Strength Characteristics of Normally Consolidated Silt - Clay Matrices, International Journal of Civil Engineering and Technology, 11(9), 2020, pp. 13-31.

https://iaeme.com/Home/issue/IJCIET?Volume=11\&Issue=9

\section{NOTATIONS}

$\mathrm{c}-$ Cohesion

$\mathrm{C}_{\mathrm{c}}$ - Coefficient of curvature

$\mathrm{C}_{\mathrm{u}}$ - Coefficient of uniformity

$\Phi$ - Angle of internal friction

$\mathrm{w}_{1}$ - Liquid limit

WP - Plastic limit

e - Void ratio 
$\mathrm{q}_{\mathrm{safe}}-$ Safe bearing capacity

qult - Ultimate bearing capacity

IP - Plasticity index

SCM - Silt-clay matrix

CBR - California bearing ratio

DFS - Differential free swell

$\mathrm{D}_{10}$ - Diameter of particle corresponding to $10 \%$ finer

$\mathrm{D}_{30}$ - Diameter of particle corresponding to $30 \%$ finer

$\mathrm{D}_{60}$ - Diameter of particle corresponding to $60 \%$ finer

D - Depth of foundation

B - Width of foundation

\section{INTRODUCTION}

With the rapid growth of demography, industrialisation and modernisation, there has been advancement in all spheres of human activities. This has generated the necessity of large scale construction of various structures. The site selection, construction and installation are made on the basis of merely functional considerations whereas their suitability from foundation engineering point of view is not given proper attention. Foundation engineers often come across complex situations when natural subsoil is too weak, having low bearing capacity and/or excessive settlements and thus affecting the general stability and functional requirements of structures.

Clay minerals are electrochemically very active. The presence of even small amount of clay can appreciably alter the engineering properties of soil mass. When $50 \%$ of the soil deposit consists of particles having diameter $0.002 \mathrm{~mm}$ or less, the deposit is termed as clay. When the percentage of clay content is about $50 \%$, the soil particles of larger diameter get suspended in the clay matrices and have little effect on the properties of soil mass. Kaolinite, Illite and Montmorillonite are some of the more important clay minerals present in soil ${ }^{1}$. There are several experimental and theoretical works done by the various geotechnical researchers ${ }^{2}$ to 14 . It has been observed in their studies that the geotechnical properties of soils such as liquid limit, plastic limit, cohesion and angle of internal friction, etc. depend upon the soil type, void ratio, degree of saturation, soil structure, stress history and nature of pore fluid.

Soil around Kahalgaon in the district of Bhagalpur of Bihar and Raj Mahal in the district of Sahebganj of Jharkhand has high percentage of kaolinite which may cause foundation problems. At present, no systematic information is available for the design of foundations in these areas. Hence research and development effort is needed to develop suitable techniques to overcome the problems of low bearing capacity and settlement of foundations. A systematic study is required to find out the most appropriate percentage of kaolinite in the siltclay matrices for ground improvement of soils in these areas.

The present paper gives away the results of the research work made in the above directions by the authors. Soil samples of saturated normally consolidated silt - clay matrices (SCM) containing various percentage of kaolinite were prepared and standard triaxial compression tests were conducted on the samples of different silt - clay matrices. The test results were then used to calculate the strength of the soil samples of the silt - clay matrices under different pressures. 


\section{FABRICATION OF INSTRUMENT FOR PREPARING REMOULDED SAMPLES OF SILT-CLAY MATRICES}

\subsection{Modified Oedometer Instrument}

In the field, soil slurry is deposited every year on each other by transportation and they get consolidated by its overburden pressure. To simulate the same condition in the laboratory, it is required to consolidate the soil slurry of slit - clay matrices by dead load placed by any means. Soil slurry is highly compressible and it gives rise to instantaneous load causing excess pore water pressure in the soil. The standard oedometer instrument cannot be used for preparing the samples because its range is up to $10 \mathrm{~mm}$ only. But for preparation of samples from the soil slurry, a deformation between $50 \mathrm{~mm}$ to $100 \mathrm{~mm}$ depending on the types of soil is required. Hence to achieve a greater consolidation, it was required to modify the oedometer instrument which fulfilled the requirements. To achieve the above goal, an instrument which could consolidate up to $100 \mathrm{~mm}$ was fabricated and is shown in Fig. 1.

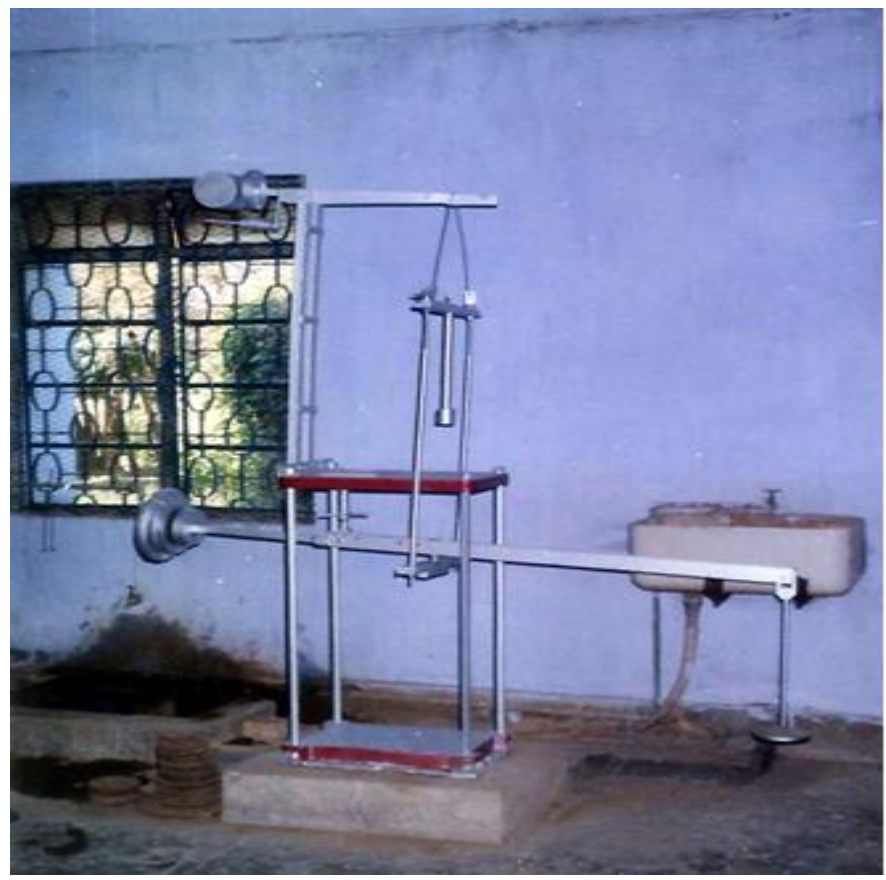

Figure 1 Modified Oedometer Instrument

\subsection{Experimental Set-up}

Let

$\mathrm{W}_{1}=$ Reaction produced to the mould

$\mathrm{W}_{2}=$ Weight applied at the free end

$l_{1}=$ distance from the reaction $\mathrm{W}_{1}$ to the fixed end $=46 \mathrm{~mm}$

$l_{2}=$ distance from the reaction $\mathrm{W}_{2}$ to the fixed end $=550 \mathrm{~mm}$.

From Fig. 1,

$\begin{array}{cc}\mathrm{W}_{1} \times \mathrm{l}_{1}=\mathrm{W}_{2} \times \mathrm{l}_{2} & \\ \mathrm{~W}_{1} & \mathrm{l}_{2} \\ ------- & = \\ \mathrm{W}_{2} & \mathrm{l}_{1}\end{array}$

If $\quad \delta_{1}=$ deflection produced under the load $\mathrm{W}_{1}$

$\delta_{2}=$ deflection produced under the load $\mathrm{W}_{2}$ 
Since $\mathrm{W}_{1}$ and $\mathrm{W}_{2}$ are constant, $\delta$ is proportional to length

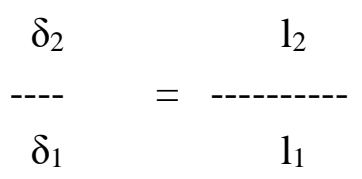

From equation (15) and (16), one gets

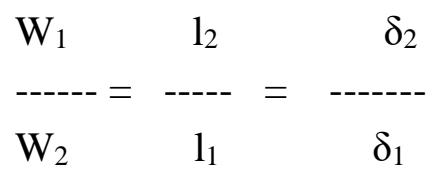

Hence in order to increase the deflection under the applied load on CBR mould, the lever arm reaction was required to be increased. Therefore, the schematic line diagram of the increased lever arm is shown in Fig. 2 in which $l_{1}$ and $l_{2}$ were kept as $270 \mathrm{~mm}$ and $1270 \mathrm{~mm}$ respectively. In this instrument the load was placed on the oedometer arm which transferred 4.70 times more load on CBR mould through ram.

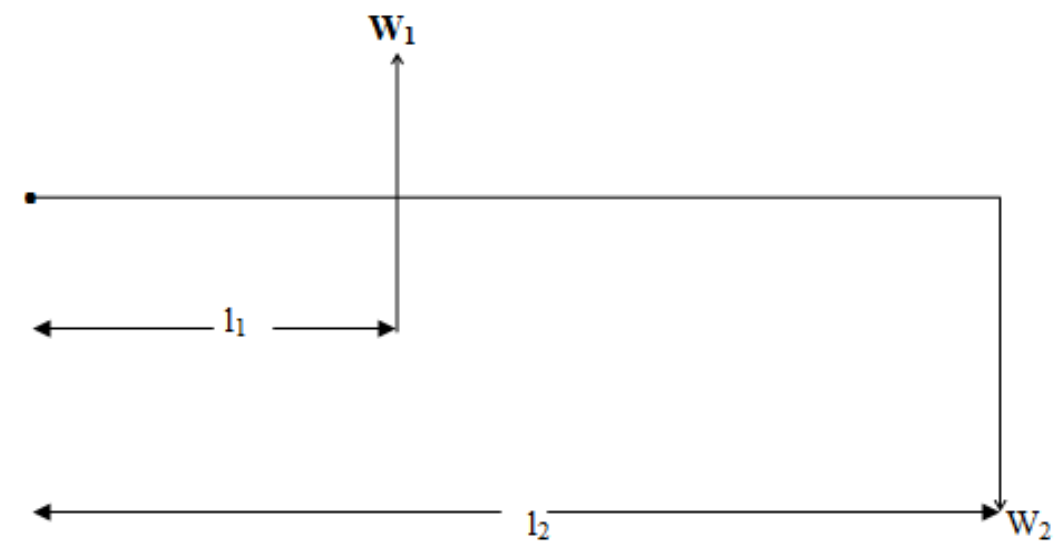

Figure 2 Schematic Working Diagram of Modified Oedometer Instrument

\subsection{Modified CBR Mould}

In the field, the drainage is in the vertical direction as well as in the radial direction. Hence to increase the rate of consolidation, small holes of diameter $1 \mathrm{~mm}$ and $10 \mathrm{~mm}$ apart were made on the cylindrical surface, top circular plate and base plate of the CBR mould.

\section{TEST PROCEDURE}

The detailed test procedure starting from the preparation of laboratory controlled silt-clay matrices to the determination of geotechnical properties are given below:

\subsection{Preparation of Silt-Clay Matrix Samples}

Soil used for preparation of silt - clay matrices were local Ganga's silt and naturally deposited kaolinite of Kahalgaon and Rajmahal regions. Properties of materials used for preparing silt clay matrices are given in Table 1. A known dry weight of clay (kaolinite) and dry mix of the known amount of silt were added and their matrices are shown in Table 2. The numerical prefix attached to the SCM designation represents the percentage of clay by weight in the silt - clay matrices. Remoulded samples were prepared by consolidating the soil slurry. Water was added in the amount twice that of the liquid limit of the silt-clay matrix to get the slurry of the sample. All care was taken to remove as much air from the sample as possible and the slurry was allowed to stand for 24 hours so as to get it saturated. 
Table 1 Properties of Materials

\begin{tabular}{|l|l|l|}
\hline \multicolumn{1}{|c|}{ Properties } & \multicolumn{1}{c|}{ Local silt (OSCM) } & \multicolumn{1}{c|}{ Kaolinite (100SCM) } \\
\hline Grain Size Analysis & ---- & --- \\
Clay & $01.50 \%$ & $32.00 \%$ \\
Silt & $63.50 \%$ & $42.00 \%$ \\
Sand (Fine) & $35.00 \%$ & $26.00 \%$ \\
$\mathrm{D}_{10}$ & $0.0092 \mathrm{mn}$ & $0.00043 \mathrm{~mm}$ \\
$\mathrm{D}_{30}$ & $0.0200 \mathrm{~mm}$ & $0.00160 \mathrm{~mm}$ \\
$\mathrm{D}_{60}$ & $0.0400 \mathrm{~mm}$ & $0.01500 \mathrm{~mm}$ \\
$\mathrm{C}_{\mathrm{u}}$ & 4.350 & 34.88 \\
$\mathrm{C}_{\mathrm{c}}$ & 1.090 & 0.40 \\
\hline Consistency limit & & \\
Liquid limit & 32.65 & 39.37 \\
Plastic limit & 23.00 & 27.80 \\
Plasticity index & 9.65 & 12.60 \\
\hline Soil classification & $\mathrm{ML}$ & $\mathrm{MI}$ \\
\hline \% Free swell & - & $30.76 \%$ \\
\% DFS & - & $13.33 \%$ \\
\hline
\end{tabular}

Wattman filter paper was cut in sizes and placed on the perforated base and around the radial drainage cylindrical surface of the modified CBR mould. The slurry was then transferred to the modified CBR mould and left for 24 hours for consolidation. The soil surface was properly levelled and covered with filter paper and placed perforated circular plate on the top of soil and left again for 24 hours. The CBR mould was then placed on the modified oedometer instrument for consolidation. The axial pressures on the samples were increased gradually upto $150 \mathrm{kN} / \mathrm{m}^{2}$ which was similar to that followed in the consolidation test. The loading pattern shown in Fig. 2 confirms to the I.S. specification for consolidation test. The soil was allowed to get consolidated under each load for 24 hours. Three dimensional drainage was allowed during consolidation. This process yielded a block sample. The standard triaxial test soil samples of $38 \mathrm{~mm}$ diameter and $76 \mathrm{~mm}$ high for one series of tests were extracted from this block sample.

Table 2 Test Results of Soil Classification

\begin{tabular}{|c|c|c|c|c|c|c|c|c|c|}
\hline \multirow[t]{2}{*}{$\begin{array}{l}\text { SI } \\
\text { No }\end{array}$} & \multirow[t]{2}{*}{$\begin{array}{c}\text { SCM } \\
\text { Designation }\end{array}$} & \multicolumn{3}{|c|}{$\begin{array}{c}\text { Grain Size Distribution } \\
\text { in \% }\end{array}$} & \multirow[t]{2}{*}{$\begin{array}{l}\text { Specific } \\
\text { gravity }\end{array}$} & \multicolumn{3}{|c|}{ Atterberg's limit } & \multirow[t]{2}{*}{$\begin{array}{l}\text { Soil type } \\
\text { classification }\end{array}$} \\
\hline & & $\begin{array}{l}\text { Fine } \\
\text { sand }\end{array}$ & Silt & Clay & & $\begin{array}{c}\text { Liquid } \\
\text { limit } \\
w_{l}\end{array}$ & $\begin{array}{c}\text { Plastic } \\
\text { limit } \\
\mathbf{w}_{\mathbf{p}}\end{array}$ & $\begin{array}{c}\text { Plastic } \\
\text { Index } \\
\text { IP }_{\mathbf{P}}\end{array}$ & \\
\hline 1 & $0 \mathrm{SCM}$ & 35.00 & 63.50 & 01.50 & 2.71 & 32.65 & 23.0 & 9.65 & ML \\
\hline 2 & $10 \mathrm{SCM}$ & 34.10 & 61.25 & 04.55 & 2.70 & 32.7 & 23.1 & 9.6 & ML \\
\hline 3 & $20 \mathrm{SCM}$ & 33.20 & 59.20 & 07.60 & 2.68 & 32.8 & 23.2 & 9.6 & ML \\
\hline 4 & $30 \mathrm{SCM}$ & 32.30 & 57.05 & 10.65 & 2.65 & 33.0 & 23.4 & 9.6 & ML \\
\hline 5 & $40 \mathrm{SCM}$ & 31.40 & 54.90 & 13.70 & 2.64 & 33.3 & 23.6 & 9.7 & ML \\
\hline 6 & $50 \mathrm{SCM}$ & 30.50 & 52.75 & 16.75 & 2.62 & 33.7 & 23.9 & 9.8 & ML \\
\hline 7 & $60 \mathrm{SCM}$ & 29.60 & 50.60 & 19.80 & 2.61 & 34.2 & 24.2 & 10.0 & ML \\
\hline 8 & $70 \mathrm{SCM}$ & 28.70 & 48.54 & 22.85 & 2.60 & 34.8 & 24.6 & 10.2 & ML \\
\hline 9 & $80 \mathrm{SCM}$ & 27.80 & 46.30 & 25.90 & 2.59 & 35.7 & 25.1 & 10.6 & MI \\
\hline 10 & $90 \mathrm{SCM}$ & 26.90 & 44.15 & 28.95 & 2.59 & 37.0 & 25.8 & 11.2 & MI \\
\hline 11 & $100 \mathrm{SCM}$ & 26.00 & 42.00 & 32.00 & 2.58 & 39.37 & 27.8 & 12.6 & MI \\
\hline
\end{tabular}

The above procedure was repeated for samples containing different percentages of kaolinite (clay) i.e. $0 \%, 10 \%, 20 \%, 30 \%, 40 \%, 50 \%, 60 \%, 70 \%, 80 \%, 90 \%$ and $100 \%$ of kaolinite by weight. 


\subsection{Determination of geotechnical Properties of silt-clay matrices}

The liquid limit, plastic limit, void ratio, cohesion and angle of internal friction were determined in the laboratory for each sample as per the recommendation of Bureau of Indian standard for different tests. The test results of the classification of various silt-clay matrices used herein were given in Table 2.

\section{TEST RESULTS AND DISCUSSIONS}

\subsection{Test Results}

The test results have been presented from Fig. 3 to Fig. 21. Fig. 3 represents the variation of liquid limit with the variation of per cent clay content in SCM soil whereas Fig. 4 represents the variation of plastic limit with the variation of per cent clay content in SCM soil samples. The curve obtained in Fig. 5 represents the variation of plasticity index with the variation of per cent clay content of SCM soil samples. Fig. 6 represents the variation of plasticity index with the liquid limit of different SCM soil samples.

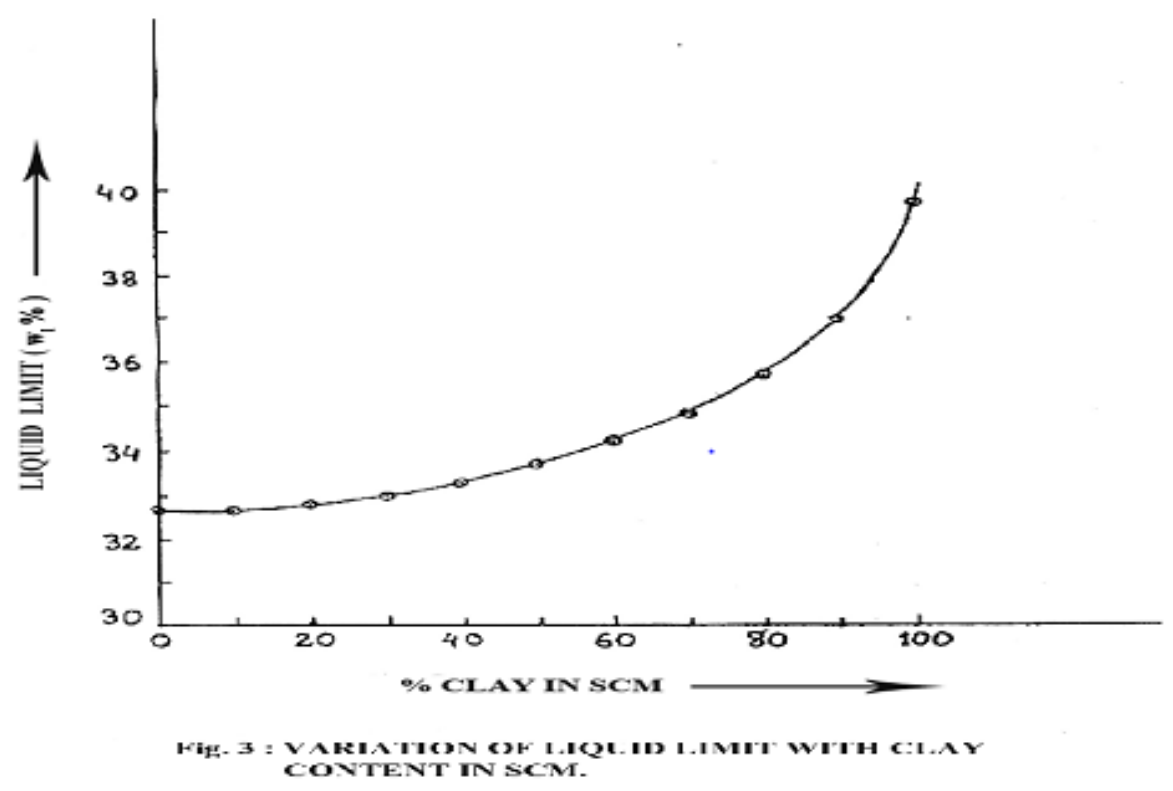

Fig. 7 shows the variation of void ratio with the consolidation pressure for different SCM soil samples. The curve obtained in Fig. 7 reflects that the void ratio is decreasing with increase in the consolidation pressure. Upto $100 \mathrm{kN} / \mathrm{m}^{2}$ consolidation pressure, void ratio decreases considerably. For the consolidation pressure more than $100 \mathrm{kN} / \mathrm{m}^{2}$, decrease in the void ratio is too small and in $60 \mathrm{SCM}$, this variation is practically negligible. In relatively large size particles, the pore water would be more easily removed and the particles would find it easier to readjust them so that on the application of consolidation pressure, there would initially be a large reduction in void ratio and consequently, a continuing small decrease is noticed as the pressure is increased. $60 \mathrm{SCM}$ gives the minimum void ratio as compared to other SCM soil samples for all the consolidation pressures.

Fig. 8 shows the variation of cohesion with per cent clay content in SCM soil samples. The value of cohesion increases upto $60 \mathrm{SCM}$ and thereafter, it decreases with the increase in the per cent of clay content. Fig. 9 shows the variation of angle of internal friction with per cent clay content in SCM soil samples. The value of internal friction decreases with the increase in the per cent of clay content. Fig. 10 shows the variation of liquid limit with the angle of internal friction. The value of angle of internal friction decreases as liquid limit increases. Fig. 11 shows the variation of plasticity index with the angle of internal friction. 
The value of angle of internal friction decreases while plasticity increases. Figs. 12, 13 and 14 show the Mohr's circle diagrams of consolidated undrained conditions for 0 SCM, 60 SCM and 100 SCM.

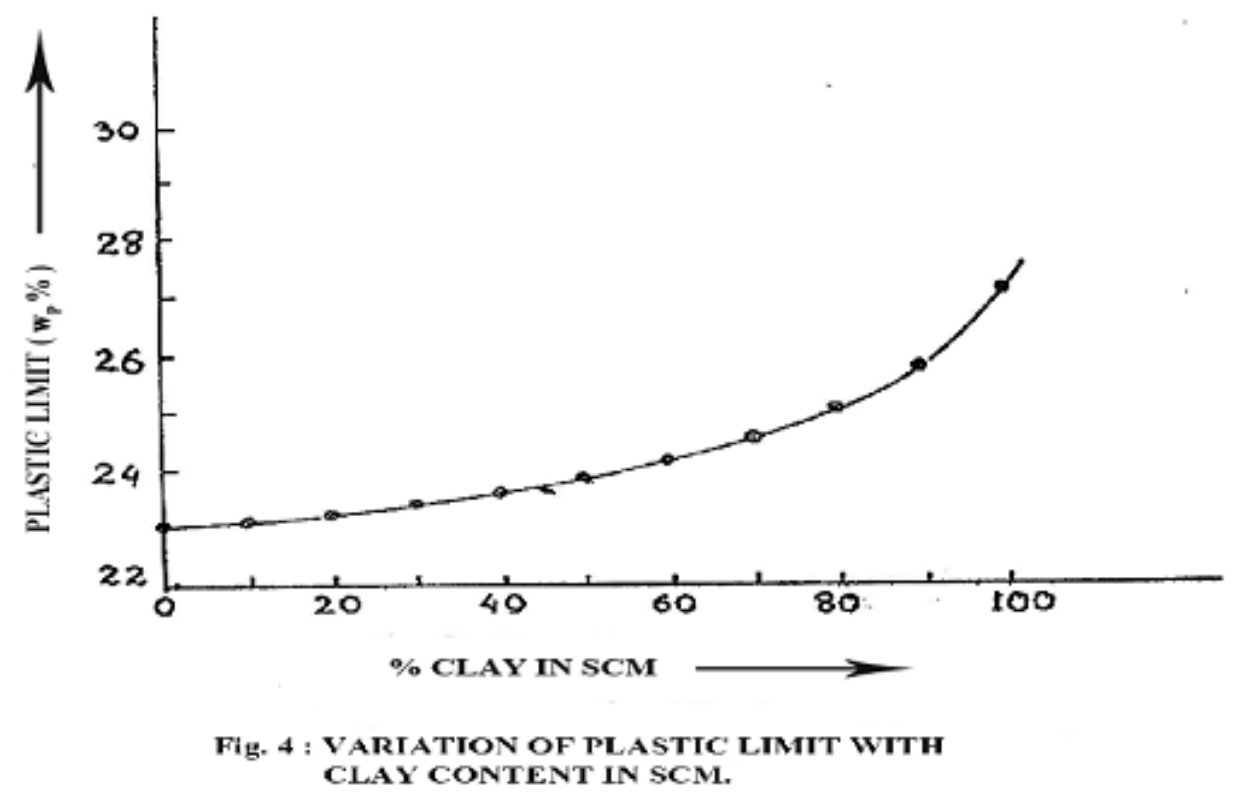

Fig. 15 represents the variation of bearing capacity (ultimate and safe) with per cent of clay content in SCM soil samples. $60 \mathrm{SCM}$ has shown the highest bearing capacity with respect to 0 SCM and 100 SCM soil samples. This may be attributed to higher density and cohesion. Increase in cohesion increases the passive resistance considerably resulting into higher value of ultimate and safe bearing capacity.

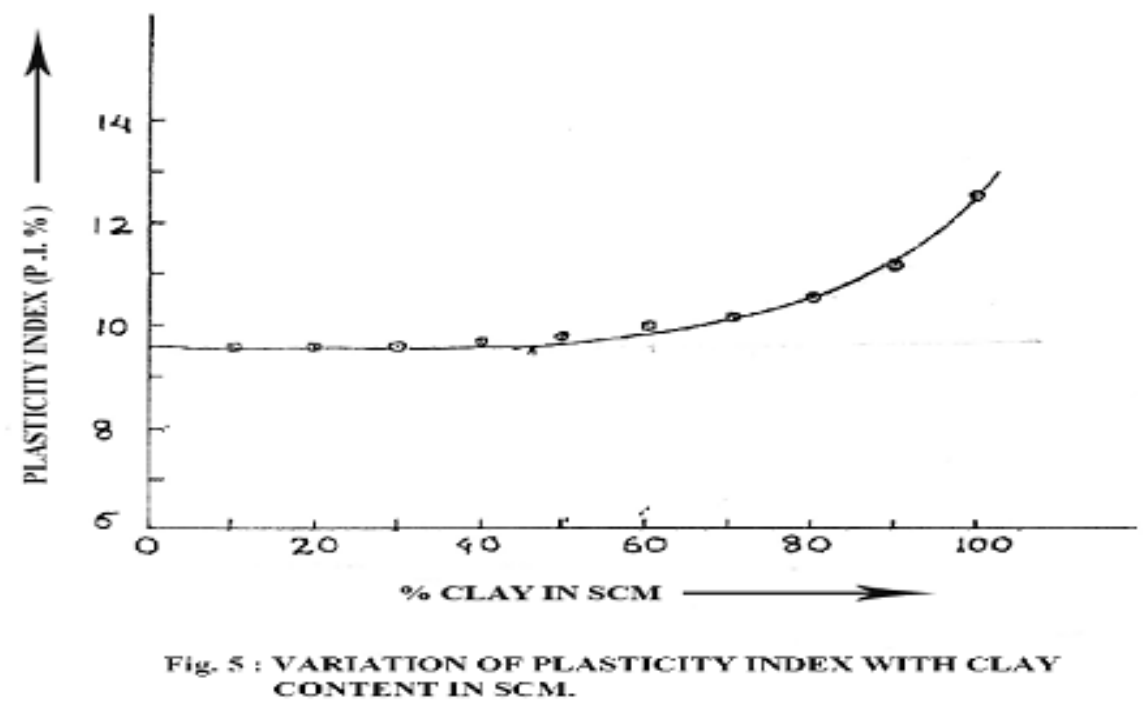

Fig. 16 represents the variation of safe bearing capacity with depth of foundation or depth / width (D/B) ratio. Safe bearing capacity has been observed to increase with depth of foundation. At lower D/B ratio, the value of safe bearing capacity of the $0 \mathrm{SCM}$ is less than that of the $60 \mathrm{SCM}$ up to 2.5. At about D/B ratio of 2.7, the value of safe bearing capacity of 0 SCM and 60 SCM soil samples becomes the same. And beyond D/B ratio of 2.7, the value of safe bearing capacity for 0 SCM becomes more than that of the 60 SCM. This phenomenon 
indicates that at higher $\mathrm{D} / \mathrm{B}$ ratio, angle of internal friction plays an important role in determining the safe bearing capacity whereas for lower D/B ratio, the effect of cohesive strength of soil is more prominent.

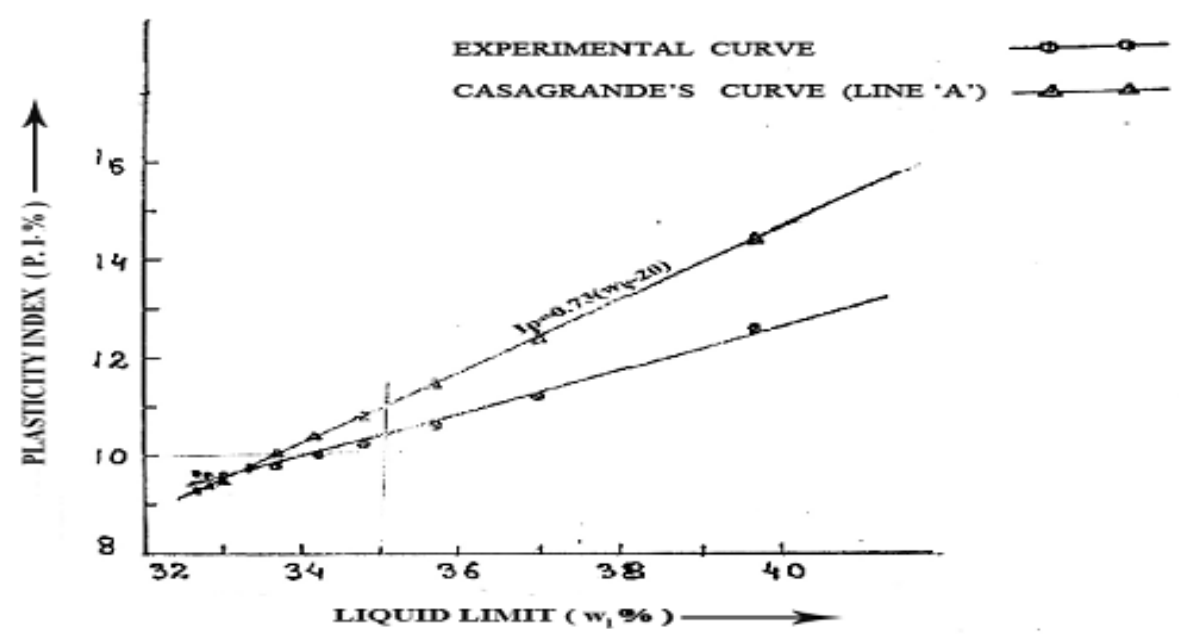

Fig. 6 : VARIATION OF PLASTICI TY INDEX WITH LIQUHD LIMT

Fig. 17 represents the variation of safe bearing capacity with width of footing. Safe bearing capacity appears to decrease up to $2 \mathrm{~m}$ width and for more than $2 \mathrm{~m}$ width, the safe bearing capacity slightly increases in all SCM soil samples. It has been observed that the value of safe bearing capacity is the highest for 60 SCM.

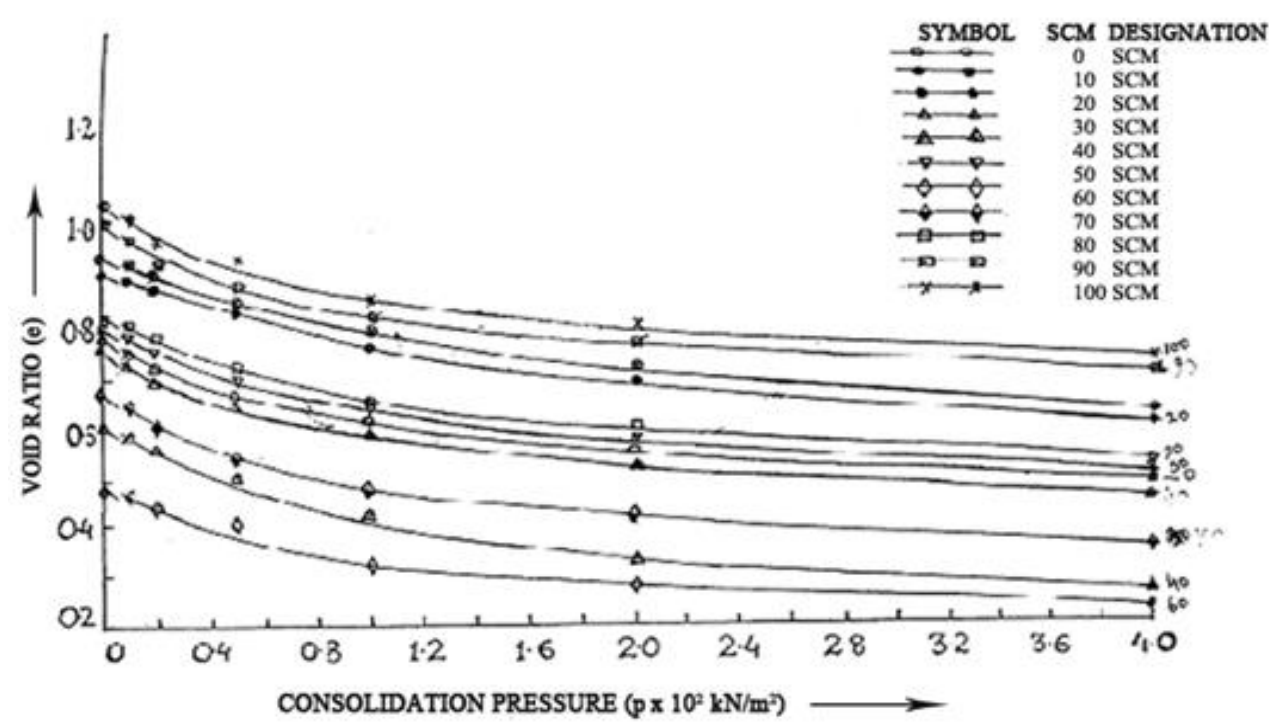

Fig. 7 : VARIATION OF VOID RATIO WITH CONSOLIDATION PRESSURE

Figs. 18, 19, and 20 represent the variation of different components of safe bearing capacity with width of footing for 0 SCM, 60 SCM and 100 SCM.. Cohesion and surcharge parts have been observed to decrease with the increase in the width of footing. The weight of the failure surface component of the safe bearing capacity increases linearly with the increase of the width of footing. Upto $2.5 \mathrm{~m}$ width, influence of decrease in depth factor remains dominant, hence the safe bearing capacity to decreases. Beyond $2.5 \mathrm{~m}$ width, influence of weight of failure surface part becomes dominant. Hence safe bearing capacity keeps on 
increasing with increase in width of footing for all SCM soil samples. In $60 \mathrm{SCM}$, the cohesion part is dominating over the weight of failure part whereas in $0 \mathrm{SCM}$, the weight of failure part is dominating.

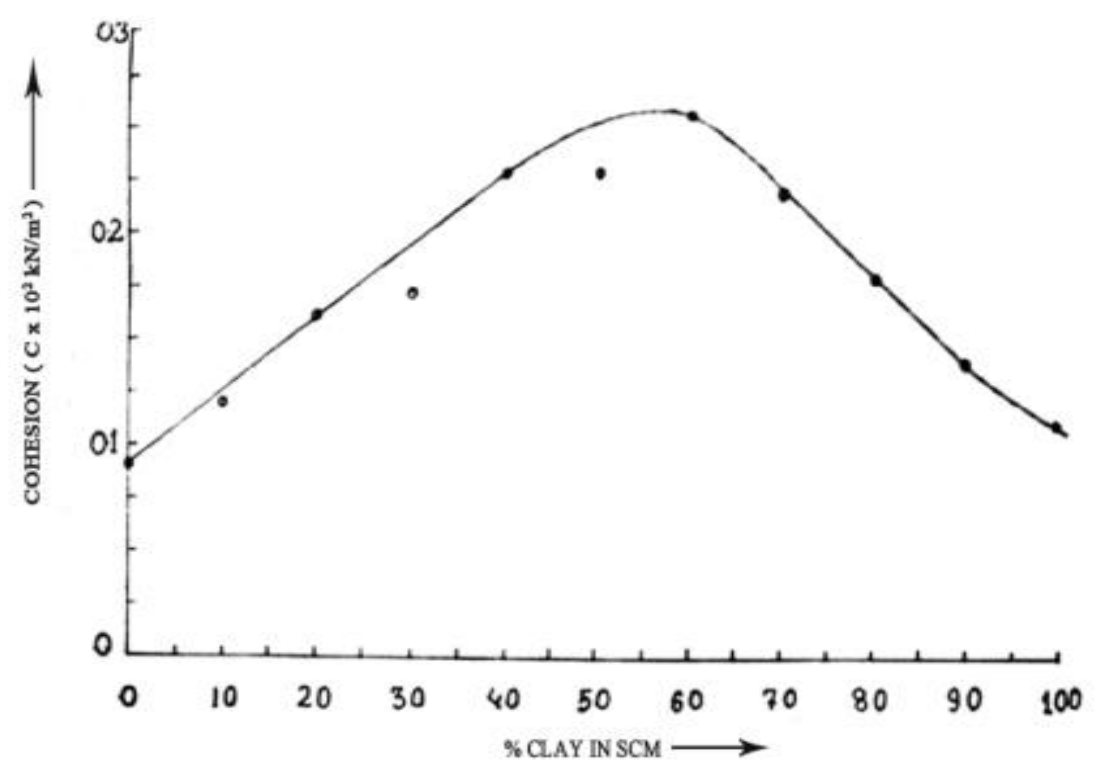

Fig. 8 : VARIATION OF COHESION WITH CLAY CONTENT IN SCM

Fig. 21 represents the variation of safe bearing capacity with per cent clay content in SCM of soil. Safe bearing capacity is either slightly increasing $(B=1 \mathrm{~m})$ or decreasing $(B=6 \mathrm{~m})$ up to $30 \mathrm{SCM}$, beyond which the value of safe bearing capacity is increasing up to $60 \mathrm{SCM}$. The value of safe bearing capacity is the highest at 60 SCM in both cases. Beyond 60 SCM, the value of safe bearing capacity is decreasing sharply.

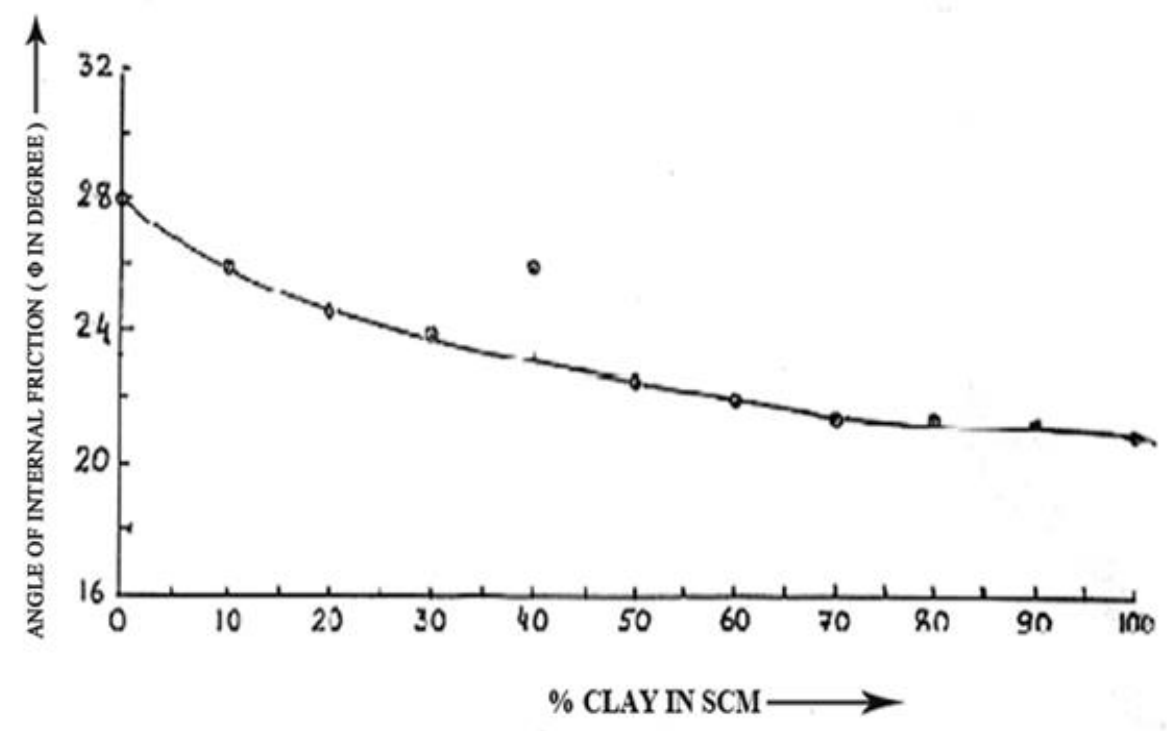

Fig. 9 : VARIATION OF ANGLE OF INTERNAL FRICTION WITH CLAY CONTENT IN SCM

\subsection{Discussion of Test Results}

Silt and kaolinite are fine grained soil. $\mathrm{D}_{10}$ of silt is about 20 times $\mathrm{D}_{10}$ of kaolinite. The kaolinite fill voids between silt particles and consequently, coats the silt particle surface and hence, modifying the cohesive behaviour of soil. 


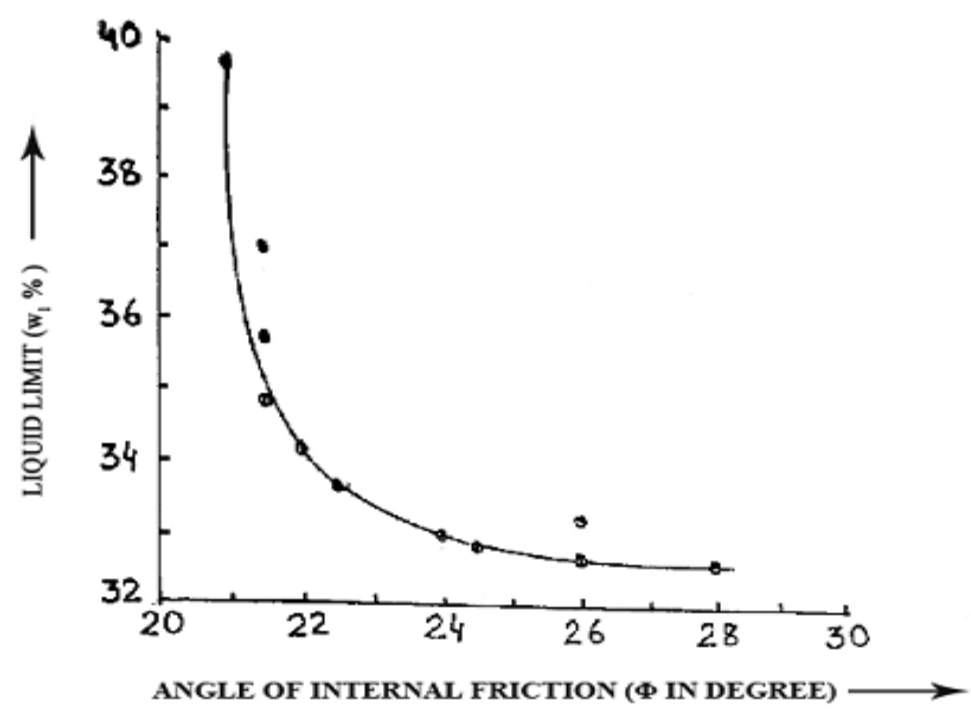

Fig. 10 : VARIATION OF INTERNAL FRICTION WITH LIQUID LIMIT

From Figs. 3 to 5, it is reflected that there is an increase in liquid limit, plastic limit and plasticity index with the increase of the clay content in SCM which is also shown in Table 2. Plasticity Index (P.I.) remains constant (about 9\%) up to 60 SCM and beyond that, P.I. increases abruptly. A decrease in the particle size would be accompanied by an increase in total surface and therefore an increase in plasticity index would be expected. Also repeated wetting and moderate drying frequently tend to increase the plasticity of clay mineral.

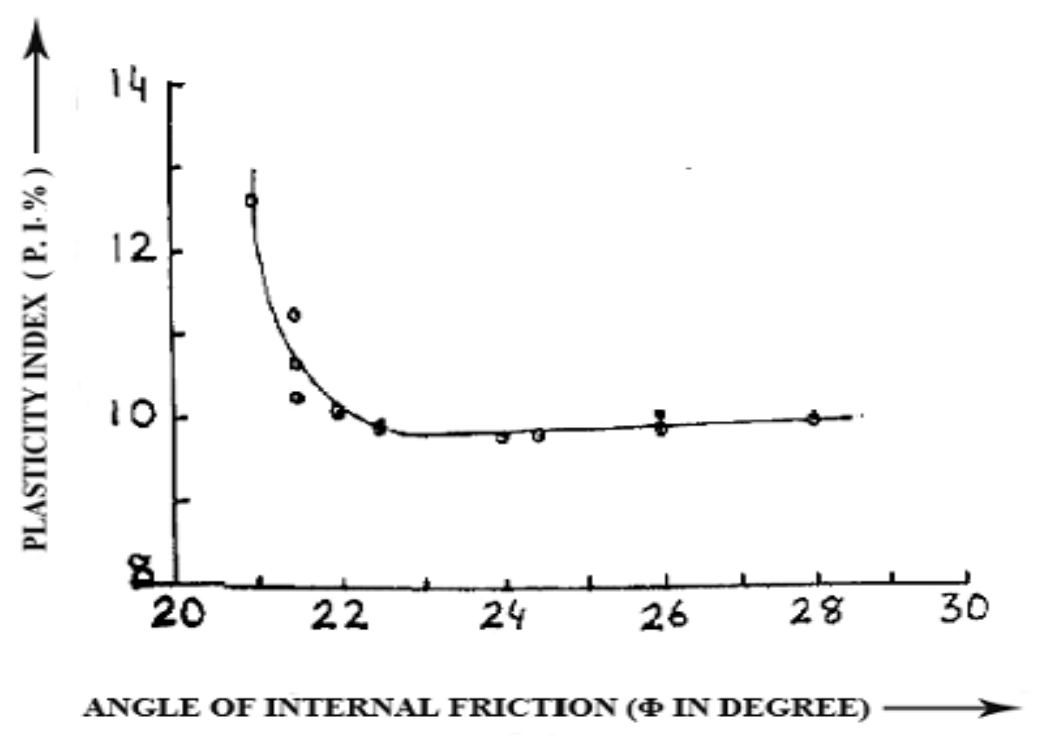

Fig. 11 : VARIATION OF ANGLE OF INTERNAL FRICTION WITH PLASTICITY INDEX

The curve shown in Fig. 6 indicates that P.I. increases with the increase of liquid limit. The experimental curve is below the Casagrande's curve for liquid limit higher than 33 . Different SCM soils lie below A-line having an inorganic silts and being classified as ML and MI [5]. This shows that SCM soil samples have low to medium compressibility. P.I. of different SCM has more than 7 as shown in Table 2. 


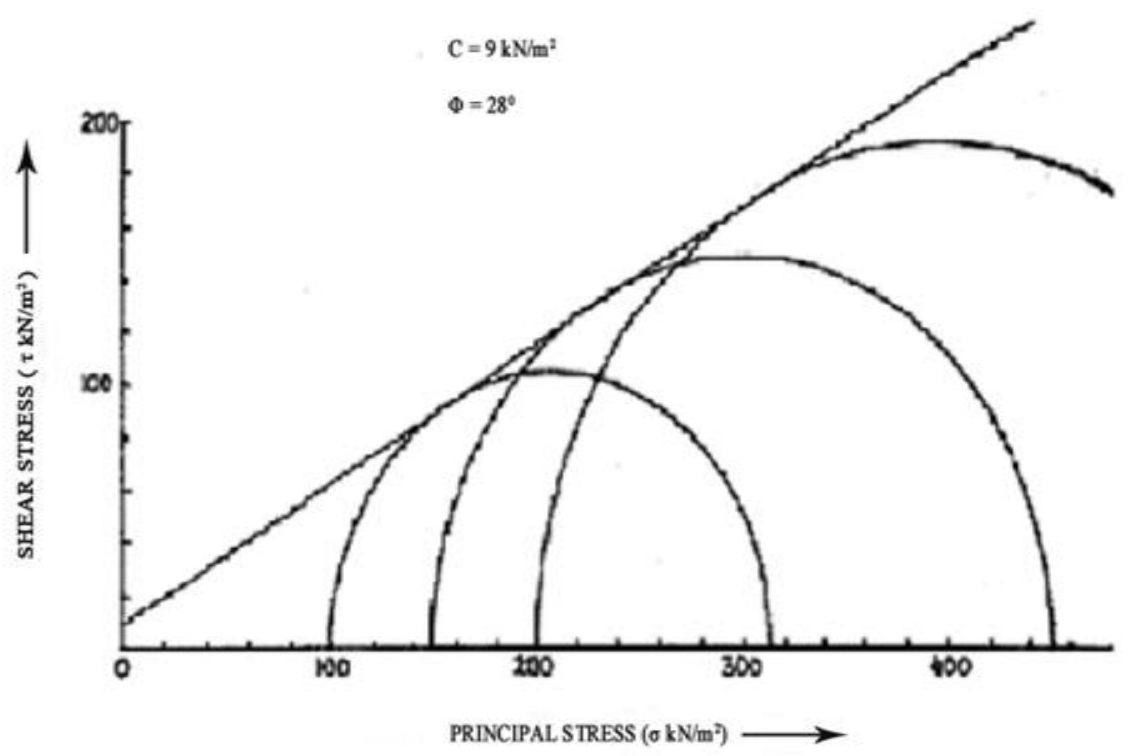

Fig. 12 : MOHR'S CIRCLE FOR O SCM

The curve shown in Fig. 7 indicates that void ratio is decreasing with increase in consolidation pressure. Upto $100 \mathrm{kN} / \mathrm{m}^{2}$ consolidation pressures, void ratio decreases considerably and thereafter decrease in the void ratio is too small. 60 SCM gives the minimum void ratio as compared to other SCM for all the consolidation pressures.

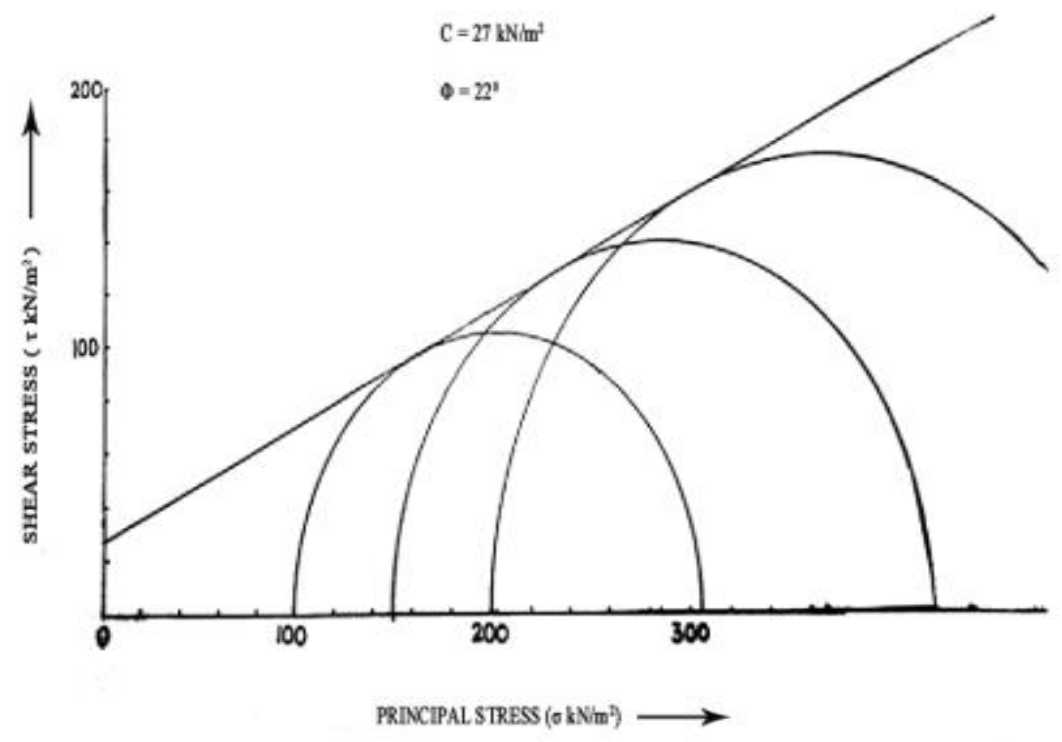

Fig. 13 : MOHR'S CIRCLE FOR 60 SCM

The curve shown in Fig. 8 indicates that the value of the cohesion increases upto 60 SCM and thereafter it decreases with increase in the per cent of clay content in the soil samples. It is seen that with the increase in the per cent of clay, the dry density decreases gradually in small amount. This is indicative of the fact that the structural formation of clay is soft and medium as compared to the situation when the silt is not fully immersed in the clay. It means that the inter-particle distance has increased in such SCM samples which contain larger amount of clays resulted in the decrease in the value of cohesion (c) above 60 SCM as shown in Table 3. 
Shear Strength Characteristics of Normally Consolidated Silt - Clay Matrices

Table 3 Abstract of Geotechnical Properties of Different Silt-Clay Matrices

\begin{tabular}{|c|c|c|c|c|c|c|c|c|c|c|c|c|c|c|c|c|}
\hline \multirow[b]{2}{*}{$\begin{array}{l}\dot{z} \\
\dot{m}\end{array}$} & \multirow{2}{*}{ 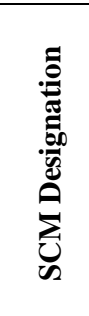 } & \multirow{2}{*}{ 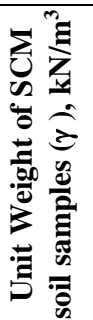 } & \multirow{2}{*}{ 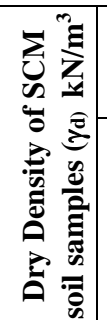 } & \multicolumn{2}{|c|}{$\begin{array}{l}\text { Triaxial } \\
\text { Test } \\
\text { Results } \\
\end{array}$} & \multicolumn{3}{|c|}{$\begin{array}{c}\text { Shear Strength, } \\
\tau\left(\mathrm{kN} / \mathrm{m}^{2}\right) \text { at Cell } \\
\text { Pressure }\end{array}$} & \multicolumn{4}{|c|}{$\begin{array}{l}\text { Ultimate Bearing Capacity qult } \\
\left(\mathbf{K N} / \mathbf{m}^{2}\right)\end{array}$} & \multirow{2}{*}{ 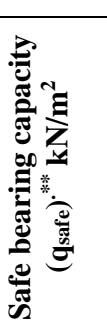 } & \multicolumn{3}{|c|}{$\begin{array}{c}\left(\sigma_{1}-\sigma 3\right)_{\mathrm{f}} \\
\text { at cell pressure }\end{array}$} \\
\hline & & & & 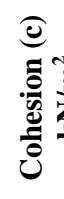 & 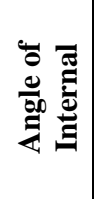 & $\frac{\mathfrak{z}}{3}$ & 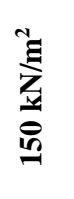 & 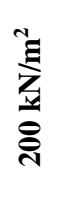 & 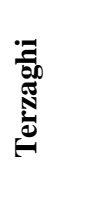 & 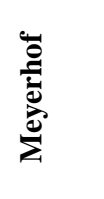 & 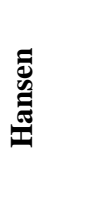 & 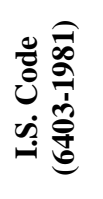 & & $\frac{\mathfrak{z}}{\frac{\pi}{8}}$ & 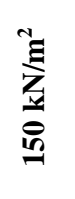 & $\frac{\text { Z }}{\text { Z }}$ \\
\hline 1 & $\begin{array}{c}0 \\
\mathrm{SCM} \\
\end{array}$ & 20.3 & 16.0 & 09 & 28 & 95 & 132 & 164 & 316.86 & 364.07 & 408.57 & 338.79 & 135.50 & 212 & 302 & 394 \\
\hline 2 & $\begin{array}{c}10 \\
\text { SCM }\end{array}$ & 19.7 & 15.9 & 12 & 26 & 90 & 124 & 160 & 317.46 & 358.93 & 404.12 & 338.98 & 135.60 & 198 & 280 & 360 \\
\hline 3 & $\begin{array}{c}20 \\
\mathrm{SCM}\end{array}$ & 19.4 & 15.7 & 15 & 24.5 & 88 & 118 & 152 & 328.46 & 367.49 & 414.91 & 352.08 & 140.83 & 194 & 268 & 340 \\
\hline 4 & $\begin{array}{c}30 \\
\text { SCM }\end{array}$ & 19.3 & 15.5 & 16 & 24 & 86 & 116 & 148 & 326.29 & 363.82 & 410.22 & 349.05 & 139.68 & 192 & 267 & 336 \\
\hline 5 & $\begin{array}{c}40^{*} \\
\mathrm{SCM}\end{array}$ & 19.1 & 15.2 & 23 & 26 & 106 & 142 & 176 & 462.86 & 524.54 & 587.84 & 494.96 & 197.98 & 236 & 316 & 400 \\
\hline 6 & $\begin{array}{c}50 \\
\mathrm{SCM}\end{array}$ & 19.2 & 15 & 23 & 22.5 & 84 & ---- & 142 & 378.01 & 417.29 & 471.47 & 406.31 & 162.52 & 203 & 242 & 324 \\
\hline 7 & $\begin{array}{c}60 \\
\text { SCM }\end{array}$ & 19.1 & 15 & 27 & 22 & 90 & 118 & 146 & 405.00 & 447.93 & 500.37 & 436.55 & 174.62 & 207 & 272 & 324 \\
\hline 8 & $\begin{array}{c}70 \\
\text { SCM }\end{array}$ & 18.6 & 14.6 & 22 & 21.5 & 80 & 108 & 138 & 341.46 & 372.60 & 421.41 & 365.41 & 146.16 & 189 & 272 & 308 \\
\hline 9 & $\begin{array}{c}80 \\
\text { SCM }\end{array}$ & 18.5 & 14.2 & 18 & 21.5 & 76 & 106 & 132 & 296.72 & 323.76 & 366.32 & 317.66 & 127.06 & 174 & 232 & 292 \\
\hline 10 & $\begin{array}{c}90 \\
\text { SCM }\end{array}$ & 18.3 & 14.0 & 16 & 21.5 & 74 & 102 & 128 & 273.64 & 298.57 & 337.87 & 293.04 & 117.22 & 168 & 228 & 288 \\
\hline 11 & $\begin{array}{c}100 \\
\text { SCM }\end{array}$ & 18.0 & 13.4 & 11 & 21 & 72 & 98 & 126 & 213.34 & 231.79 & 261.63 & 228.69 & 91.48 & 148 & 206 & 266 \\
\hline
\end{tabular}

An optimum quantity of finer material to be mixed with relatively coarser material for maximum cohesion is $60 \mathrm{SCM}$ (60\% kaolinite). As a micro-structural hypothesis, it can be envisaged that the silt particles get enmeshed into the clay clogging making the contribution of silt particles less and less as the clay content is increased (for 60 SCM to 100 SCM). From Fig. 8 and Table 2, it is clear that per cent of clay fraction in 60 SCM is $19.80 \%$ On the left side of the optimum value (60 SCM), silt is dominant whereas on the right side of the said optimum value, kaolinite is dominant.

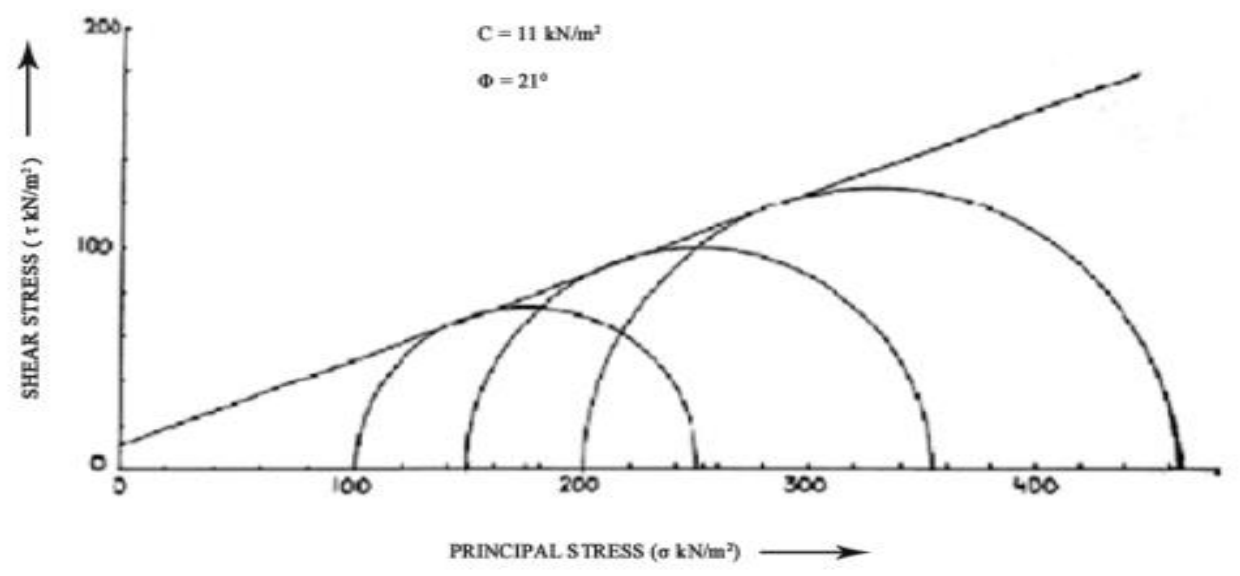

Fig. 14 : MOHR'S CIRCLE FOR 100 SCM 


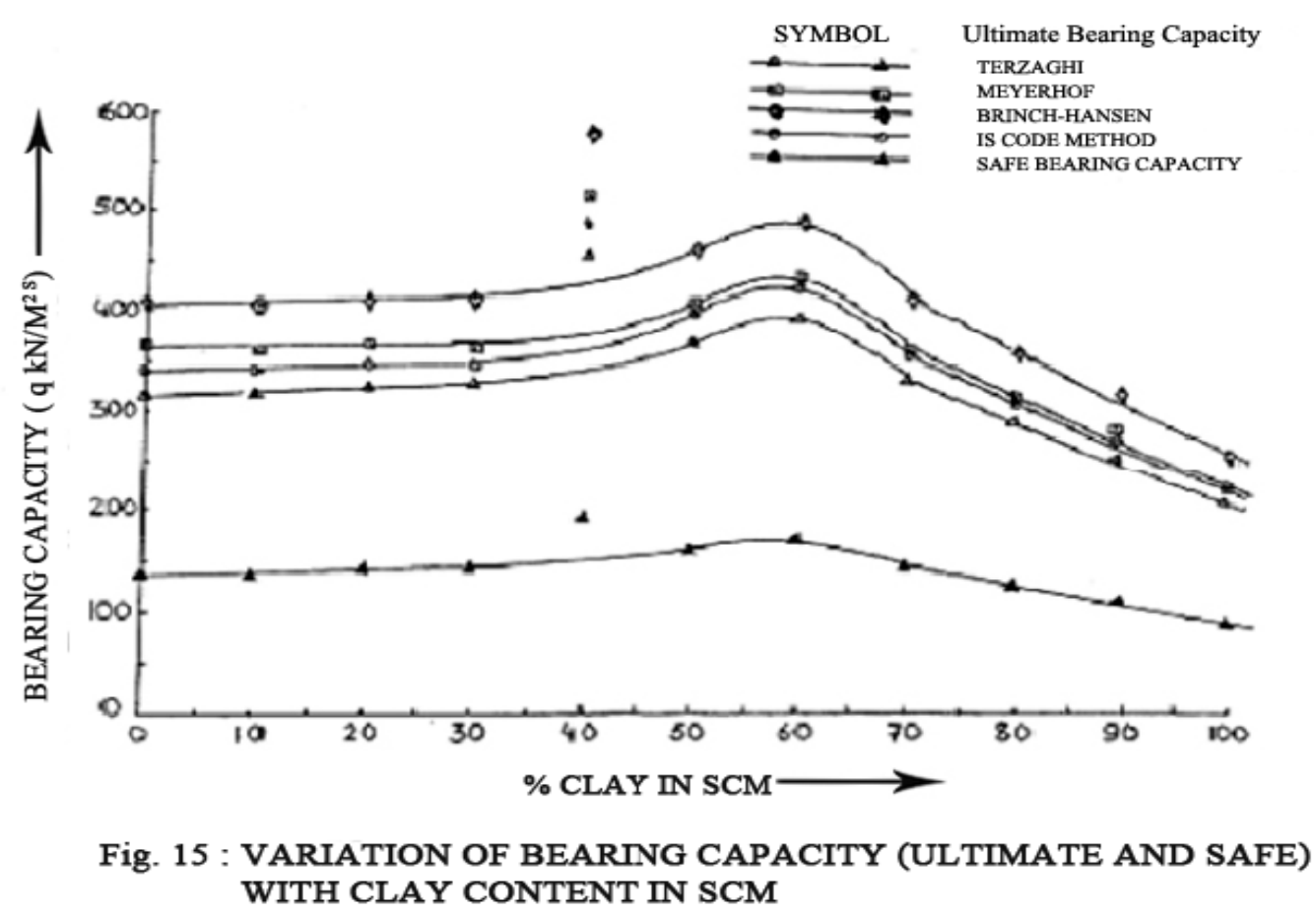

The curve shown in Fig. 9 indicates that the value of $\phi$ decreases with the increase in the per cent of clay content in SCM. This decrease in $\phi$ is due to nature of the particles of kaolinite used in the preparation of samples. At $60 \mathrm{SCM}$, value of $\phi$ is reduced by $22 \%$ which is well compensated by increasing cohesion which is of the order of $200 \%$ increase. Bearing capacity of 60 SCM largely depends on cohesion as shown in Table 3.

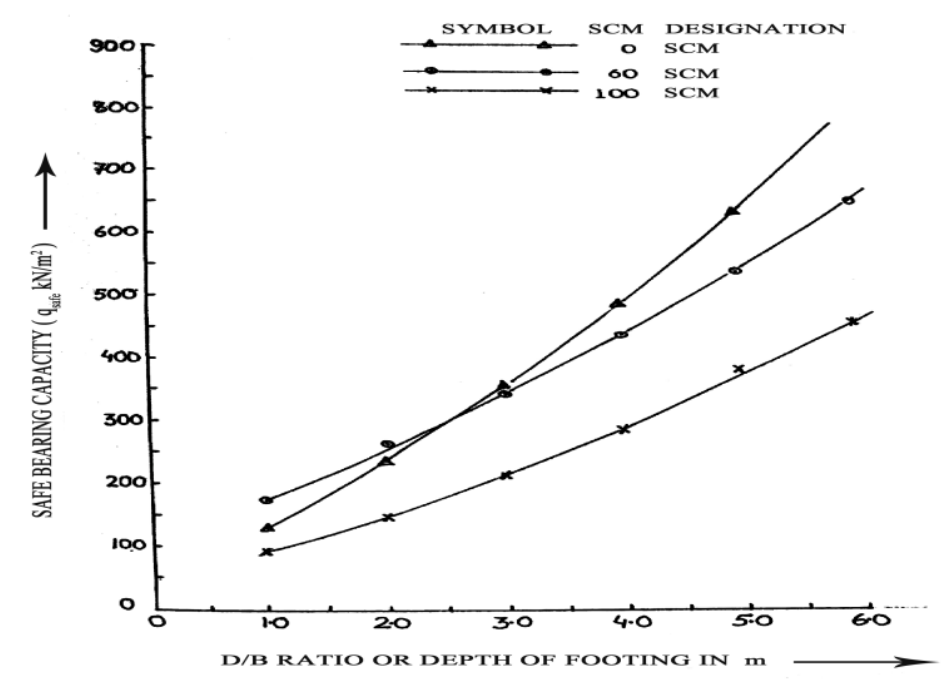

FIg. 16 : VARIATION OF SAFE BEARING CAPACITY WITH D/B OR

DEPTH OF FOOTING IN SCM 
The curves given in Fig. 10 and Fig. 11 reflect that the value of $\phi$ increases with the decrease in the liquid limit and plasticity index. This decrease in $\phi$ is due to decrease in the lubrication action and decrease in the thickness of adsorbed water layers as well.

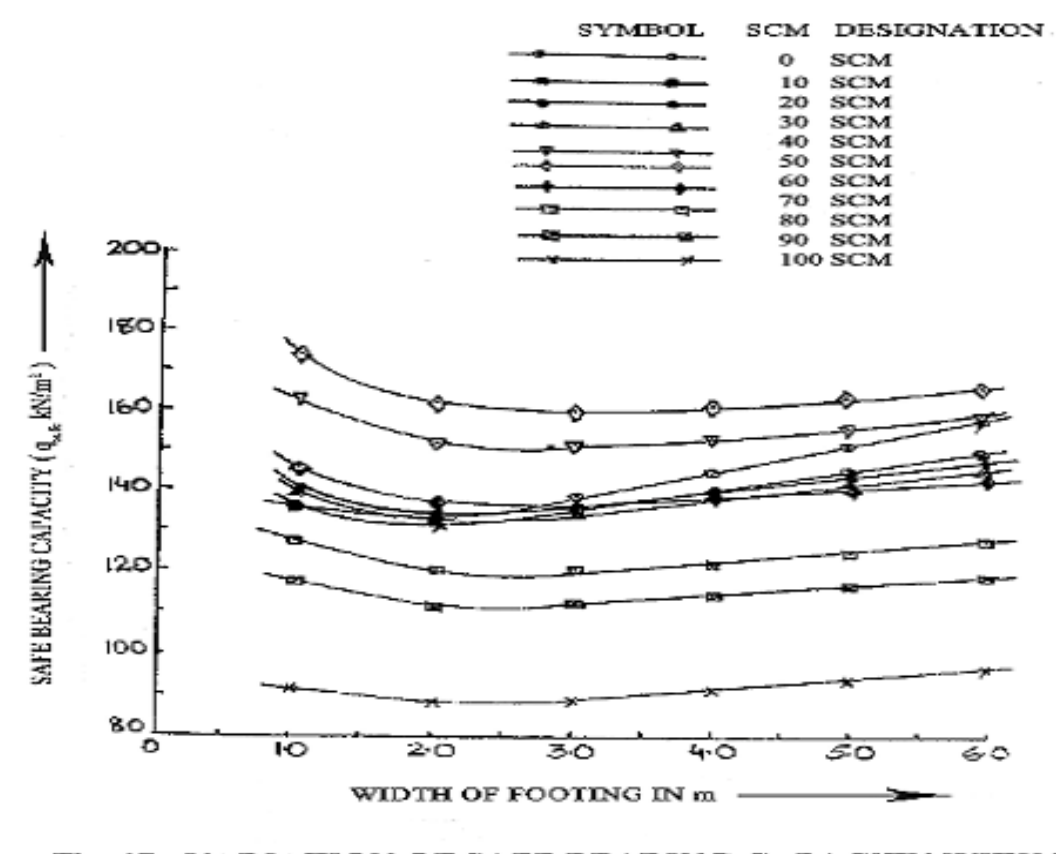

FIg. 17 : VARIATON OF SAFE BEARING CAPACITV WITII WIOTII OF FUOTLEG IN SCM

The curve shown in Fig. 15 indicates that 0 SCM has higher bearing capacity as compared to 100 SCM. 60 SCM has shown the highest bearing capacity. This may be attributed to the higher density and unit cohesion as compared to 100 SCM. Increase in the unit cohesion increases the passive resistance considerably resulting into higher value of the ultimate bearing capacity. Abstract of geotechnical properties of different silt - clay matrices are shown in Table 3. Study of Fig. 15 reveals the following points regarding variation of bearing capacity with kaolinite in SCM:

- Bearing capacity of silt alone is better than kaolinite.

- There is a gradual increase in the bearing capacity with increase in kaolinite from 10 to $60 \mathrm{SCM}$.

- When kaolinite per cent increases beyond 60 SCM, bearing capacity has been found to decrease.

- Safe bearing capacity has been found to be $135.50 \mathrm{kN} / \mathrm{m}^{2}$ for $0 \mathrm{SCM}, 174.62 \mathrm{kN} / \mathrm{m}^{2}$ for $60 \mathrm{SCM}$ and $91.48 \mathrm{kN} / \mathrm{m}^{2}$ for $100 \mathrm{SCM}$ when the width of the footing is $1 \mathrm{~m}$.

Field engineers in this zone take a safe bearing capacity of $100 \mathrm{kN} / \mathrm{m}^{2}$ for silt, whereas for kaolinite it is much smaller. Addition of $40 \%$ local silt such as Ganga's silt to the local kaolinite deposits increases safe bearing capacity by $190.88 \%$ which made the foundations more cost effective. 
Table 4 Variation of Safe Bearing Capacity ( $\left.\mathrm{q}_{\mathrm{safe}}\right)$ with D/B Ratio for Different Silt-Clay Matrices

\begin{tabular}{|c|c|c|c|c|c|c|c|c|c|c|c|c|c|c|c|c|}
\hline \multirow{6}{*}{$\begin{array}{l}\dot{z} \\
\dot{n}\end{array}$} & \multirow{6}{*}{ 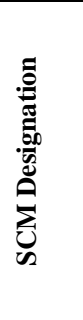 } & \multirow{6}{*}{ 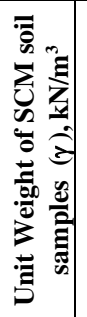 } & \multirow{6}{*}{ 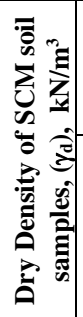 } & \multirow{4}{*}{\multicolumn{2}{|c|}{$\begin{array}{c}\text { Triaxial } \\
\text { Test } \\
\text { Results }\end{array}$}} & \multicolumn{11}{|c|}{ Safe Bearing capacity $\left(\mathrm{q}_{\text {safe }}\right), \mathrm{kN} / \mathrm{m}^{2}$ (I.S. Code:6403-1981, FoS=2.5) } \\
\hline & & & & & & \multirow{2}{*}{\multicolumn{5}{|c|}{$\frac{D=1 m}{B}$}} & \multirow{2}{*}{\multicolumn{6}{|c|}{$\frac{\mathbf{B}=1 \mathbf{m}}{\mathrm{D}}$}} \\
\hline & & & & & & & & & & & & & & & & \\
\hline & & & & & & 6m & 5m & $4 \mathbf{m}$ & 3m & $2 \mathrm{~m}$ & $\mathbf{1 m}$ & $2 \mathbf{m}$ & $3 \mathbf{m}$ & 5 & & $6 \mathbf{m}$ \\
\hline & & & & \multirow{2}{*}{ 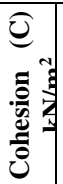 } & \multirow[b]{2}{*}{ 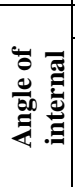 } & \multicolumn{5}{|c|}{ D/B } & \multicolumn{6}{|c|}{ D/B } \\
\hline & & & & & & 0.17 & 0.2 & 0.25 & $\mathbf{0 . 3 3}$ & 0.5 & 1 & 2 & 3 & 4 & 5 & 6 \\
\hline 1 & $\begin{array}{c}0 \\
\text { SCM } \\
\end{array}$ & 20.3 & 16.0 & 09 & 28 & 159.36 & 152.34 & 145.16 & 138.42 & 133.31 & 135.50 & 234.64 & 350.38 & 485.44 & 635.70 & $\begin{array}{c}802.3 \\
2 \\
\end{array}$ \\
\hline 2 & $\begin{array}{c}10 \\
\text { SCM } \\
\end{array}$ & 19.7 & 15.9 & 12 & 26 & 150.92 & 145.99 & 139.59 & 135.18 & 130.95 & 135.60 & 225.11 & 326.96 & 443.22 & 573.98 & $\begin{array}{c}707.6 \\
0 \\
\end{array}$ \\
\hline 3 & $\begin{array}{c}20 \\
\text { SCM }\end{array}$ & 19.4 & 15.7 & 15 & 24.5 & 149.41 & 144.95 & 140.34 & 135.72 & 134.15 & 140.83 & 223.52 & 317.60 & 425.42 & 543.69 & $\begin{array}{c}676.6 \\
1 \\
\end{array}$ \\
\hline 4 & $\begin{array}{c}30 \\
\text { SCM }\end{array}$ & 19.3 & 15.5 & 16 & 24 & 146.53 & 142.49 & 138.37 & 134.17 & 133.09 & 139.62 & 218.25 & 309.71 & 411.31 & 524.12 & $\begin{array}{c}650.7 \\
6 \\
\end{array}$ \\
\hline 5 & $\begin{array}{c}40 \\
\text { SCM }\end{array}$ & 19.1 & 15.2 & 23 & 26 & 200.79 & 197.06 & 191.38 & 188.15 & 186.15 & 197.98 & 299.45 & 412.66 & 539.74 & 680.67 & $\begin{array}{c}836.5 \\
2 \\
\end{array}$ \\
\hline 6 & $\begin{array}{c}50 \\
\text { SCM } \\
\end{array}$ & 19.2 & 15 & 23 & 22.5 & 160.43 & 156.83 & 153.78 & 151.68 & 152.43 & 162.52 & 240.76 & 328.02 & 426.81 & 534.36 & $\begin{array}{c}652.7 \\
5 \\
\end{array}$ \\
\hline 7 & $\begin{array}{c}60 \\
\text { SCM } \\
\end{array}$ & 19.1 & 15 & 27 & 22 & 167.86 & 164.84 & 162.32 & 160.78 & 162.66 & 174.62 & 251.45 & 337.89 & 433.47 & 538.34 & $\begin{array}{c}652.5 \\
1 \\
\end{array}$ \\
\hline 8 & $\begin{array}{c}70 \\
\text { SCM } \\
\end{array}$ & 18.6 & 14.6 & 22 & 21.5 & 144.15 & 141.14 & 138.62 & 136.86 & 137.10 & 146.16 & 215.39 & 293.23 & 308.53 & 457.59 & $\begin{array}{c}581.2 \\
3 \\
\end{array}$ \\
\hline 9 & $\begin{array}{c}80 \\
\text { SCM } \\
\end{array}$ & 18.5 & 14.2 & 18 & 21.5 & 128.14 & 125.00 & 122.34 & 120.30 & 119.95 & 127.06 & 192.10 & 265.99 & 348.71 & 440.28 & $\begin{array}{c}540.6 \\
8 \\
\end{array}$ \\
\hline 10 & $\begin{array}{c}90 \\
\text { SCM } \\
\end{array}$ & 18.3 & 14.0 & 16 & 21.5 & 119.68 & 116.52 & 113.83 & 111.67 & 111.06 & 117.22 & 179.81 & 251.15 & 331.23 & 420.06 & $\begin{array}{c}517.6 \\
4 \\
\end{array}$ \\
\hline 11 & $\begin{array}{c}100 \\
\text { SCM }\end{array}$ & 18 & 13.4 & 11 & 21 & 97.36 & 94.15 & 91.42 & 89.01 & 87.75 & 91.46 & 147.40 & 211.77 & 284.59 & 382.32 & $\begin{array}{c}455.5 \\
4 \\
\end{array}$ \\
\hline
\end{tabular}

The curve shown in Fig.16 indicates that safe bearing capacity increases with depth of foundation. The value of safe bearing capacity for 100 SCM is less than that of 60 SCM for all $\mathrm{D} / \mathrm{B}$ ratios. It has been further observed that the value of safe bearing capacity of $0 \mathrm{SCM}$ is less than $60 \mathrm{SCM}$ for D/B ratio upto 2.7 whereas for D/B ratio greater than 2.7 , the value of safe bearing capacity of $0 \mathrm{SCM}$ is even greater than that of $60 \mathrm{SCM}$. This phenomenon indicates that at higher $\mathrm{D} / \mathrm{B}$ ratio, $\phi$ plays an important role for determining the safe bearing capacity whereas at lower $\mathrm{D} / \mathrm{B}$ ratio, the effect of unit cohesion of soil is more prominent. Micro- structurally, it can be assumed that at lower $\mathrm{D} / \mathrm{B}$ ratio, the grain to grain contact of 0 SCM soil is not very much pronounced with respect to that at higher D/B ratio. The safe bearing capacity for $100 \mathrm{SCM}$ is lower than that for the corresponding safe bearing capacity for $0 \mathrm{SCM}$ and $60 \mathrm{SCM}$ for the entire D/B ratio. Variation of safe bearing capacity with D/B ratio for different silt - clay matrices are shown in Table 4.

The curve shown in Fig. 17 indicates that safe bearing capacity appears to decrease upto 2 $\mathrm{m}$ width and for more than $2 \mathrm{~m}$, the safe bearing capacity slightly increases in all SCM. It has been observed that the value of safe bearing capacity is the highest for 60 SCM as shown in Table 5. 
Table 5 Variation of Safe Bearing Capacity and the Components with Respect to Width of Footing for Different Silt-Clay Matrices.

\begin{tabular}{|c|c|c|c|c|c|c|c|c|c|c|c|c|c|c|c|c|c|}
\hline \multirow[b]{3}{*}{$\begin{array}{l}\dot{0} \\
\dot{\boldsymbol{n}}\end{array}$} & \multirow{3}{*}{ 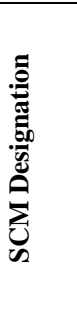 } & \multirow{3}{*}{ 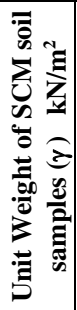 } & \multirow{3}{*}{ 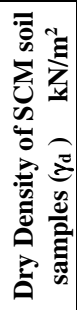 } & \multirow{2}{*}{\multicolumn{2}{|c|}{$\begin{array}{c}\text { Triaxial } \\
\text { Test } \\
\text { Results } \\
\end{array}$}} & \multicolumn{8}{|c|}{ Safe Bearing Capacity $\left(q_{\text {safe }}\right)$ kN/m² (I.S.Code : 6403 - 1981), } & \multirow{2}{*}{\multicolumn{4}{|c|}{$\begin{array}{c}\text { FoS }=2.5 \text { for } L / B=1, D=1 \mathrm{~m} \\
B=3 m\end{array}$}} \\
\hline & & & & & & \multicolumn{4}{|c|}{$\mathbf{B}=\mathbf{1 m}$} & \multicolumn{4}{|c|}{$\mathbf{B}=\mathbf{2 m}$} & & & & \\
\hline & & & & 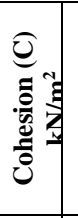 & 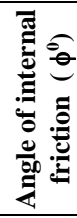 & $\begin{array}{l}\check{0} \\
\tilde{n} \\
\ddot{Z} \\
u\end{array}$ & $\begin{array}{l}\widetilde{0} \\
\tilde{D} \\
\bar{Z} \\
z \\
\frac{Z}{z}\end{array}$ & 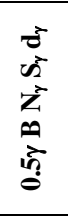 & $\stackrel{5}{\frac{\pi}{6}}$ & $\begin{array}{l}\tilde{u} \\
\tilde{n} \\
\ddot{z} \\
u\end{array}$ & 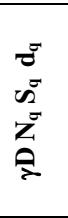 & 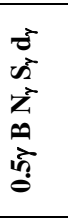 & 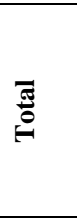 & 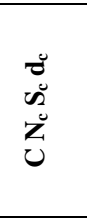 & $\begin{array}{l}\tilde{\sigma} \\
\overline{2} \\
\bar{z} \\
\bar{z}\end{array}$ & 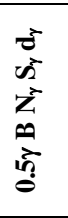 & 气ี \\
\hline 1 & $\begin{array}{c}0 \\
\text { SCM }\end{array}$ & 20.3 & 16.0 & 09 & 28.0 & 57.70 & $\begin{array}{c}68.3 \\
2 \\
\end{array}$ & 9.48 & $\begin{array}{c}135 . \\
50\end{array}$ & $\begin{array}{c}51.4 \\
0\end{array}$ & $\begin{array}{c}64.1 \\
2 \\
\end{array}$ & $\begin{array}{c}17.8 \\
0\end{array}$ & $\begin{array}{c}133.3 \\
2\end{array}$ & $\begin{array}{c}49.1 \\
4\end{array}$ & $\begin{array}{c}62.9 \\
2 \\
\end{array}$ & $\begin{array}{c}26.8 \\
9 \\
\end{array}$ & $\begin{array}{c}138 . \\
95\end{array}$ \\
\hline 2 & $\begin{array}{c}10 \\
\text { SCM } \\
\end{array}$ & 19.7 & 15.9 & 12 & 26.0 & 70.28 & $\begin{array}{c}57.7 \\
0 \\
\end{array}$ & 7.62 & $\begin{array}{c}135 . \\
60 \\
\end{array}$ & $\begin{array}{c}62.5 \\
2 \\
\end{array}$ & $\begin{array}{c}54.1 \\
2 \\
\end{array}$ & $\begin{array}{c}14.3 \\
0 \\
\end{array}$ & $\begin{array}{c}130.9 \\
4 \\
\end{array}$ & $\begin{array}{c}60.3 \\
1 \\
\end{array}$ & $\begin{array}{c}53.6 \\
1 \\
\end{array}$ & $\begin{array}{c}21.2 \\
6 \\
\end{array}$ & $\begin{array}{c}135 . \\
18 \\
\end{array}$ \\
\hline 3 & $\begin{array}{c}20 \\
\mathrm{SCM} \\
\end{array}$ & 19.4 & 15.7 & 15 & 24.5 & 82.75 & $\begin{array}{c}51.5 \\
6 \\
\end{array}$ & 6.52 & $\begin{array}{c}140 . \\
83 \\
\end{array}$ & $\begin{array}{c}73.6 \\
3 \\
\end{array}$ & $\begin{array}{c}48.3 \\
6 \\
\end{array}$ & $\begin{array}{c}12.1 \\
6 \\
\end{array}$ & $\begin{array}{c}134.1 \\
5 \\
\end{array}$ & $\begin{array}{c}70.3 \\
7 \\
\end{array}$ & $\begin{array}{c}47.4 \\
5 \\
\end{array}$ & $\begin{array}{c}17.9 \\
0 \\
\end{array}$ & $\begin{array}{c}135 . \\
72 \\
\end{array}$ \\
\hline 4 & $\begin{array}{c}30 \\
\text { SCM } \\
\end{array}$ & 19.3 & 15.5 & 16 & 24.0 & 84.94 & $\begin{array}{c}48.6 \\
8 \\
\end{array}$ & 6.00 & $\begin{array}{c}139 . \\
62 \\
\end{array}$ & $\begin{array}{c}76.1 \\
8 \\
\end{array}$ & $\begin{array}{c}45.6 \\
6 \\
\end{array}$ & $\begin{array}{c}11.2 \\
5 \\
\end{array}$ & $\begin{array}{c}133.0 \\
9 \\
\end{array}$ & $\begin{array}{c}72.8 \\
0 \\
\end{array}$ & $\begin{array}{c}44.8 \\
0 \\
\end{array}$ & $\begin{array}{c}16.5 \\
6 \\
\end{array}$ & $\begin{array}{c}134 . \\
16\end{array}$ \\
\hline 5 & $\begin{array}{c}50 \\
\text { SCM }\end{array}$ & 19.2 & 15.0 & 23 & 22.5 & 114.30 & $\begin{array}{c}43.2 \\
2\end{array}$ & 5.00 & $\begin{array}{c}162 . \\
52\end{array}$ & $\begin{array}{c}102 . \\
27\end{array}$ & $\begin{array}{c}40.5 \\
4\end{array}$ & 9.38 & $\begin{array}{c}152.1 \\
9\end{array}$ & $\begin{array}{c}97.9 \\
4\end{array}$ & $\begin{array}{c}39.7 \\
8\end{array}$ & $\begin{array}{c}13.9 \\
4\end{array}$ & $\begin{array}{c}151 . \\
69\end{array}$ \\
\hline 6 & $\begin{array}{c}60 \\
\text { SCM } \\
\end{array}$ & 19.1 & 15.0 & 27 & 22.0 & 129.73 & $\begin{array}{c}40.4 \\
0 \\
\end{array}$ & 4.49 & $\begin{array}{c}174 . \\
62 \\
\end{array}$ & $\begin{array}{c}116 . \\
34\end{array}$ & $\begin{array}{c}37.9 \\
0 \\
\end{array}$ & 8.42 & $\begin{array}{c}162.6 \\
6 \\
\end{array}$ & $\begin{array}{c}111 . \\
20 \\
\end{array}$ & $\begin{array}{c}37.1 \\
9 \\
\end{array}$ & $\begin{array}{c}12.3 \\
9 \\
\end{array}$ & $\begin{array}{c}160 . \\
78\end{array}$ \\
\hline 7 & $\begin{array}{c}70 \\
\text { SCM } \\
\end{array}$ & 18.6 & 14.6 & 22 & 21.5 & 103.64 & $\begin{array}{c}38.3 \\
0 \\
\end{array}$ & 4.22 & $\begin{array}{c}146 . \\
16 \\
\end{array}$ & $\begin{array}{c}92.8 \\
7 \\
\end{array}$ & $\begin{array}{c}36.2 \\
4 \\
\end{array}$ & 7.98 & $\begin{array}{c}137.0 \\
9 \\
\end{array}$ & $\begin{array}{c}89.5 \\
5 \\
\end{array}$ & $\begin{array}{c}35.5 \\
6 \\
\end{array}$ & $\begin{array}{c}11.7 \\
4 \\
\end{array}$ & $\begin{array}{c}136 . \\
85 \\
\end{array}$ \\
\hline 8 & $\begin{array}{c}80 \\
\text { SCM } \\
\end{array}$ & 18.5 & 14.2 & 18 & 21.5 & 84.79 & $\begin{array}{c}38.0 \\
8 \\
\end{array}$ & 4.19 & $\begin{array}{c}127 . \\
06\end{array}$ & $\begin{array}{c}75.9 \\
7 \\
\end{array}$ & $\begin{array}{c}36.0 \\
4 \\
\end{array}$ & 7.94 & $\begin{array}{c}119.9 \\
5 \\
\end{array}$ & $\begin{array}{c}73.2 \\
6 \\
\end{array}$ & $\begin{array}{c}35.3 \\
6 \\
\end{array}$ & $\begin{array}{c}11.6 \\
8 \\
\end{array}$ & $\begin{array}{c}120 . \\
30\end{array}$ \\
\hline 9 & $\begin{array}{c}90 \\
\text { SCM } \\
\end{array}$ & 18.3 & 14.0 & 16 & 21.5 & 75.39 & $\begin{array}{c}37.6 \\
8 \\
\end{array}$ & 4.15 & $\begin{array}{c}117 . \\
22 \\
\end{array}$ & $\begin{array}{c}67.5 \\
5 \\
\end{array}$ & $\begin{array}{c}35.6 \\
6 \\
\end{array}$ & 7.84 & $\begin{array}{c}111.0 \\
5 \\
\end{array}$ & $\begin{array}{c}65.1 \\
4 \\
\end{array}$ & $\begin{array}{c}34.9 \\
9 \\
\end{array}$ & $\begin{array}{c}11.5 \\
4 \\
\end{array}$ & $\begin{array}{c}111 . \\
67 \\
\end{array}$ \\
\hline 10 & $\begin{array}{c}100 \\
\text { SCM }\end{array}$ & 18.0 & 13.4 & 11 & 21.0 & 51.12 & $\begin{array}{c}36.3 \\
8 \\
\end{array}$ & 3.98 & $\begin{array}{c}91.4 \\
8 \\
\end{array}$ & $\begin{array}{c}45.8 \\
1 \\
\end{array}$ & $\begin{array}{c}34.4 \\
3 \\
\end{array}$ & 7.51 & 87.75 & $\begin{array}{c}44.1 \\
7 \\
\end{array}$ & $\begin{array}{c}33.7 \\
0 \\
\end{array}$ & $\begin{array}{c}11.0 \\
6 \\
\end{array}$ & $\begin{array}{c}89.0 \\
1 \\
\end{array}$ \\
\hline
\end{tabular}

The curves shown in Fig. 18 to Fig. 20 indicate that cohesion and surcharge parts have been observed to decrease with the increasing width of foundation because of decrease in depth factors whereas unit cohesion, unit weight of soil, bearing capacity factors and shape factors remain constant for a given SCM. Weight of failure surface component of the bearing capacity increases linearly with the increase in width of footing upto about $2.5 \mathrm{~m}$ width, influence of decrease in depth factors remain dominant, hence safe bearing capacity too decreases. Beyond $2.5 \mathrm{~m}$ width, influence of weight of failure surface part becomes dominant. Hence safe bearing capacity keeps on increasing with increase in width of footing for all SCM. In $60 \mathrm{SCM}$, cohesion part is dominating over weight of the failure part where as in 0 SCM, weight of failure part is dominating. Variation of safe bearing capacity and the components with respect to width of footing for different silt - clay matrices are shown in Table 5.

The curve shown in Fig. 21 indicates that safe bearing capacity is either slightly increasing $(B=1 \mathrm{~m})$ or decreasing $(B=6 \mathrm{~m})$ up to $30 \mathrm{SCM}$. Beyond which the value of safe bearing capacity is increasing up to $60 \mathrm{SCM}$. The value of safe bearing capacity is highest at $60 \mathrm{SCM}$ in both cases. Beyond 60 SCM, value of safe bearing capacity is decreasing sharply which is also shown in Table 5.

A modified oedometer developed during the present research work will be useful for further research work for the preparation of soil samples with different additives. These types of tests can also be conducted on different soil matrices such as sand, kaolinite, fly ash matrices etc. However, details field investigations are required for confirmation of the above facts. Techniques have to be developed for the field application of the findings. More new areas of research are likely to emerge with progress of research in this new field. 
Krishna Nandan Prasad and Achintya
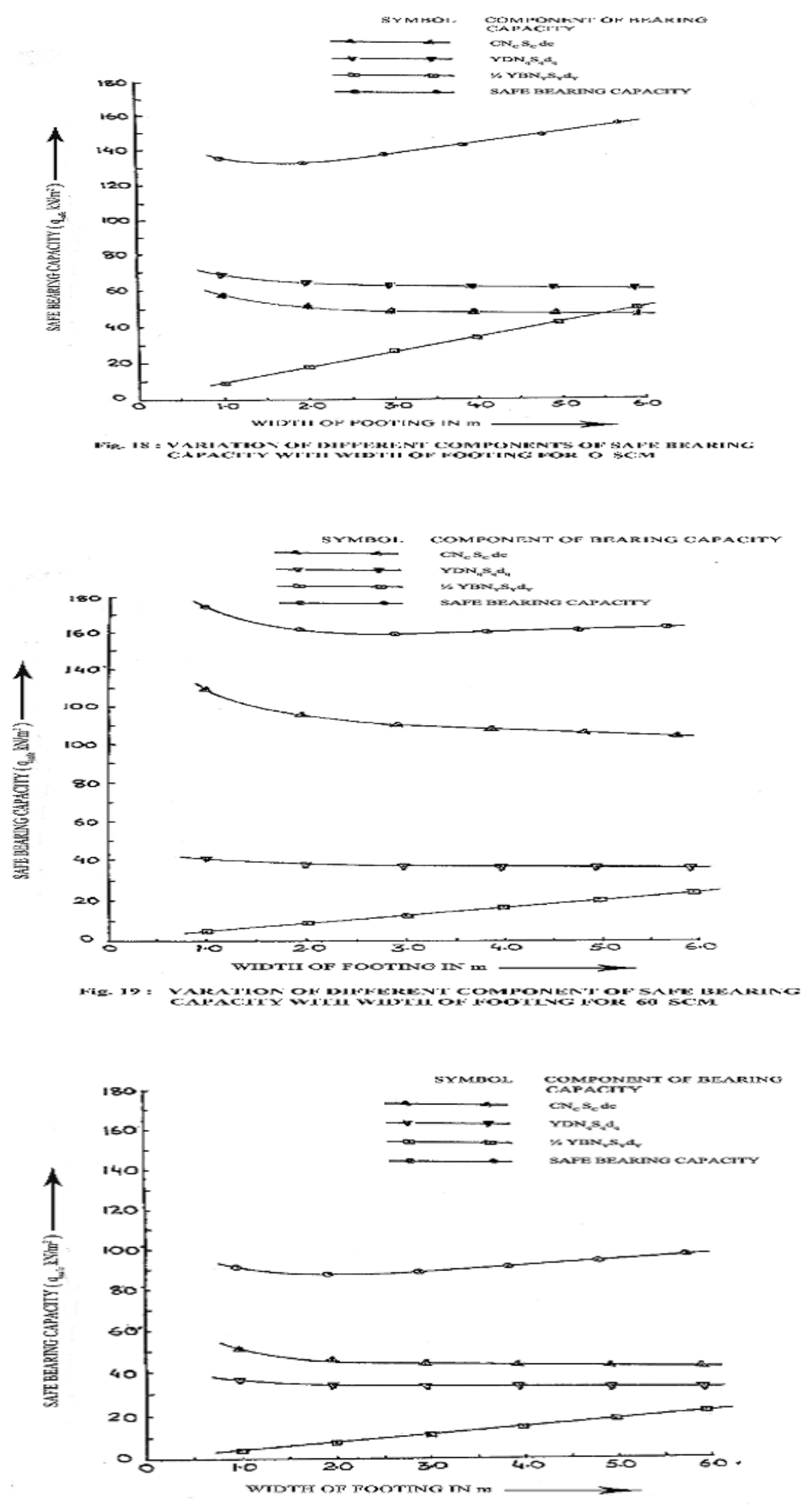

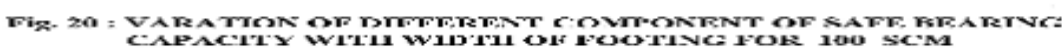




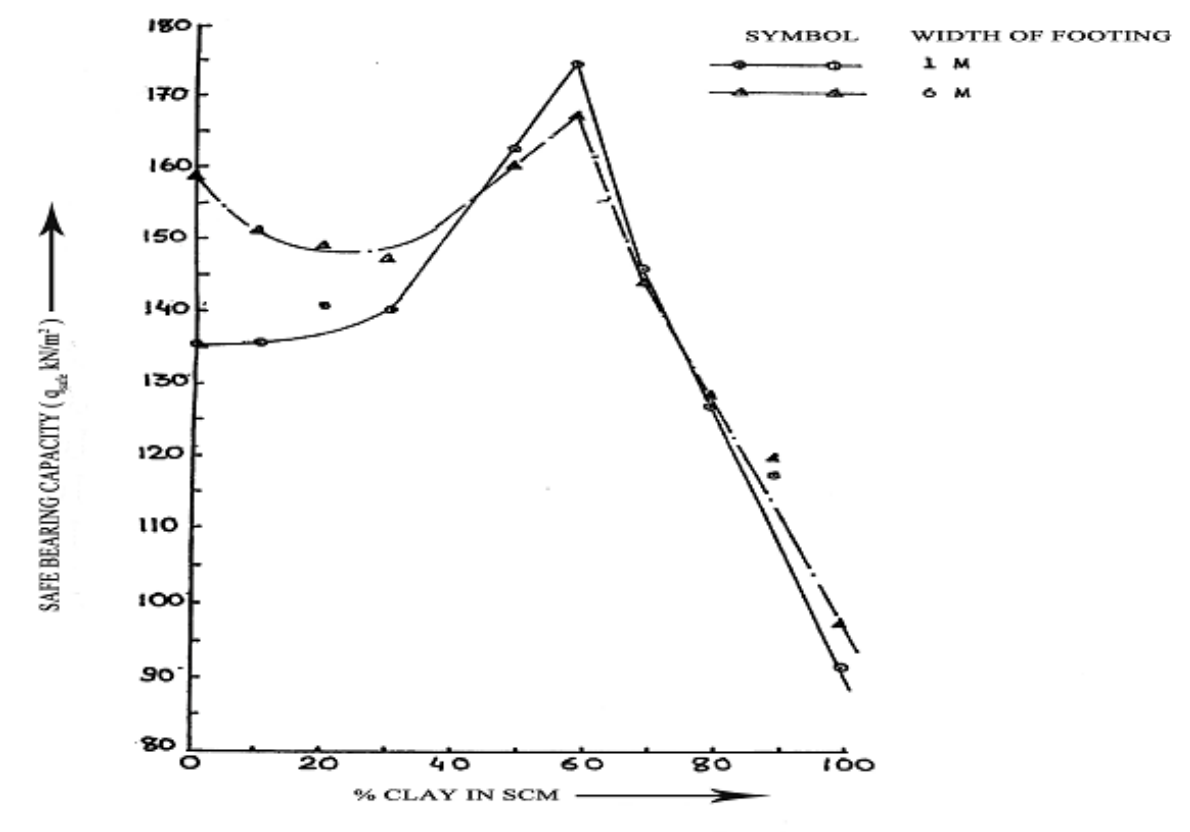

\section{CONCLUSIONS}

The shear strength behaviour of an artificially normally consolidated silt - clay matrices have been studied. The main conclusions have been drawn which are as follows:

- The value of void ratio (e) for 0 SCM to 100 SCM decreases with the increase of the effective consolidation pressure. The void ratio decreases by $20.6 \%, 33.5 \%$ and $19.4 \%$ for $0 \mathrm{SCM}, 60 \mathrm{SCM}$ and $100 \mathrm{SCM}$ respectively. The value of void ratio at $60 \mathrm{SCM}$ is the least for the pressure ranges including a denser mix.

- Soil shows $\mathrm{c}-\phi$ behaviour under consolidated undrained condition. Maximum value of unit cohesion at $60 \mathrm{SCM}$ has been observed. $\Phi$ - value changes marginally with change in the per cent clay content in SCM. 60\% kaolinite plus $40 \%$ level silt (60 SCM) would give maximum shearing strength on account of higher value of $c$.

- $60 \mathrm{SCM}$ has the highest bearing capacity (safe and ultimate) with respect to $0 \mathrm{SCM}$ and 100 SCM. This may be attributed to the higher density and cohesion as compared to $100 \mathrm{SCM}$. Increase in the unit cohesion increases the passive resistance considerably resulting into higher value of bearing capacity.

- Safe bearing capacity has been found to be $135.50 \mathrm{kN} / \mathrm{m}^{2}$ for $0 \mathrm{SCM}, 174.62 \mathrm{kN} / \mathrm{m}^{2}$ for $60 \mathrm{SCM}$ and $91.48 \mathrm{kN} / \mathrm{m}^{2}$ for $100 \mathrm{SCM}$ when the width of the footing is $1 \mathrm{~m}$.

From the study of various percentage of kaolinite with locally available silt, $60 \mathrm{SCM}$ is suitable soil mix from all considerations like bearing capacity and settlement criterion. From the experimental results, it is concluded that $60 \mathrm{SCM}$ is the best proportion for any construction work and therefore the ground improvement can be carried out by mixing of $40 \%$ local silt in the natural kaolinite deposits at Kahalgaon- Rajmahal region of Bihar and Jharkhand.

The objective of the present research work is to provide economical as well as safe foundations for the engineered structures. Based on the present research work, appropriate design of shallow foundation, earth dam, road pavement, etc. will be cost effective and will give satisfactory performance of the engineering projects. The above work aims to be of great 
help to foundation engineers, builders and construction engineers working in the aforementioned regions of Bihar and Jharkhand.

\section{REFERENCES}

[1] Grim R.E. (1962), “Applied Clay Mineralogy.” International Science in the Earth Science, McGraw Hill Book Company, INC, New York, pp. 204-277.

[2] Terzaghi, K. (1943), “Theoretical Soil Mechanics.” J. Wiley and Sons, New York.

[3] Lambe, T.W. (1951), "Soil Testing for Engineers.” John-Wiley, New York.

[4] Fagnoul, A (1965), "Shear strength of Re-moulded and Undisturbed Soils." Proceedings of the VIth International Conference on Soil Mechanics and Foundation Engineering, Vol. I, Montreal, pp. 213-216.

[5] Henkel, D.J. (1959), "The Relationship between Pore-water Pressure and Volume Change Characteristics of Saturated Clays." Geo-Technique, Vol.9. No. 3, pp.119-135.

[6] Bjerrum, L and N. E. Simons (1960), "Comparison of Shear Strength Characteristics of Normally Consolidated Clays." Proceedings of the ASCE Research Conference on the Shear Strength of Cohesive Soils, Boulder, Colorado, pp. 711-726.

[7] Gibbs, H.J., Hilf, J. W., Holts, W.G. and Walker, F.C. (1960), "Shear Strength of Cohesive Soils." Proceedings of the ASCE Research Conference on the Shear Strength of Cohesive Soils, Boulder, Colorado, pp.33-162.

[8] Hvorslev, M.J. (1960), "Physical Components of the Shear Strength of Saturated Clays." Proceedings of the ASCE Research Conference on the Shear Strength of Cohesive Soils, Boulder, Colorado, pp. 169-273.

[9] Kennedy, I.C. (1967), "Shear Strength of Soft Clay," Proc. Geo-Tech Conf., Oslo, Vol.2, pp. 49-55.

[10] Leonards, G.A. and Andersland, O.B. (1960), "The Clay Water System and the Shearing Resistance of Clays." Proceedings of the ASCE Research Conference on the Shear Strength of Cohesive Soils, Boulder, Colorado, pp. 793-818.

[11] Meyerhof, G.G. (1965), "Shallow Foundations." Journal of Soil Mechanics and Foundation Division, ASCE, Vol.91 (SM2), pp. 21-31.

[12] Schultze, E. and Horn. A. (1965), "The Shear Strength of Silt." Proceedings of the VIth International Conference on Soil Mechanics and Foundation Engineering, Vol. I, pp. 350-353.

[13] Skempton, A.W. (1951), "The Bearing Capacity of Clays." Proceedings of the Building Research Congress, London, Institution of Civil Engineers, Vol. 1, pp. 180-189.

[14] Vesic, A.S. (1973), "Analysis of Ultimate Loads of Shallow Foundations.” Journal of the Soil Mechanics and Foundation Division, ASCE, Vol. 99, No. SMI, pp. 45-73. 